\title{
Software Adoption, Employment Composition and the Skill Content of Occupations in
}

\author{
Chilean Firms *
}

\author{
Rita K. Almeida (World Bank \& IZA) \\ Ana M. Fernandes (World Bank) \\ Mariana Viollaz (CEDLAS-FCE-UNLP) ${ }^{\mathrm{c}}$
}

This version: October 21, 2018

\begin{abstract}
* This paper is a modified version of the World Bank Policy Research Working Paper 8110 with the title "Does the Adoption of Complex Software Impact Employment Composition and the Skill Content of Occupations? Evidence from Chilean Firms". Financial support from the Regional Studies Program of the Office of the Chief Economist for Latin American and the Caribbean (LCRCE) at the World Bank is gratefully acknowledged. This paper was prepared as a background paper for the Regional Study on Digital Technology Adoption, Skills, Productivity and Jobs in Latin America. We are grateful to the editor and referees as well as to Marc Schiffbauer, Marcio Cruz, Daniel Lederman, Reema Nayar, Irene Brambilla, Roberto Alvarez, Alan Fuchs, Diego Angel as well as participants at the 2016 Jobs and Development conference, 2017 ASSA conference, 2017 LACEA conference, 2017 Latin American Network on Economics of Innovation and Entrepreneurship conference, and the LAC Technology Adoption workshop (authors' workshop) for comments. We are also grateful to Roberto Alvarez, Valeria Cirillo, Sandra Peralta from INE, Chile for help with the data. Ana M. Fernandes also thanks the World Bank's Multidonor Trust Fund for Trade and Development and the Strategic Research Partnership on Economic Development for funding. The findings expressed in this paper are those of the authors and do not necessarily represent the views of the World Bank.

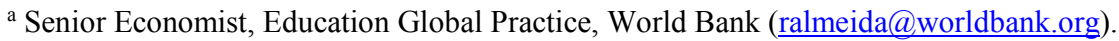

${ }^{\mathrm{b}}$ (corresponding author) Senior Economist, Trade and International Integration Unit, Development Research Group, World Bank (afernandes@worldbank.org).

c Senior Researcher, Centro de Estudios Distributivos, Laborales y Sociales (CEDLAS), Facultad de Ciencias Económicas, Universidad Nacional de La Plata (mviollaz@,cedlas.org).
\end{abstract}




\title{
Software Adoption, Employment Composition and the Skill Content of Occupations in Chilean Firms
}

\begin{abstract}
We contribute to the technology, skills and jobs debate by exploiting a novel dataset for Chilean firms between 2007 and 2013, with information on the firms' adoption of complex software used in client management, production or administration and business software packages. Instrumental variables estimates show that, in the medium run, adoption of this complex software reallocates employment away from professional and technical workers, toward administrative and unskilled workers (production and services). Adoption also increases the use of routine and manual tasks and reduces that of abstract tasks within firms. The contrast between ours and previous findings shows that labor market impacts of technology adoption hinge on the type of technology and its complementarity with the skills content of occupations.
\end{abstract}

JEL codes: J23, J24, J31, O33.

Keywords: complex software, tasks, skills, employment structure, Chile. 


\section{Introduction}

Technology adoption, and especially information and communication technology (ICT) adoption, has expanded dramatically during the last decade (World Bank, 2016). The impact of ICT on the jobs and skills demanded by employers is a topic of great interest and an important driver of future labor demand. However, a concern is that the growing use of ICT is leading to a polarization of labor markets in developed countries, whereby employment and earnings are shifting away from middle-skilled jobs into both high-skilled and low-skilled jobs (Autor \& Dorn, 2013; Frey \& Osborne, 2013; Autor, 2014). Some authors argue that this change is explained by changes in the task composition of jobs following digital technology adoption, as computers carry out activities that follow automatized and explicit rules and procedures (Autor, Levy \& Murnane, 2003). More recently technologies are advancing even faster (for example, robots and artificial intelligence), automating tasks typically performed by more educated workers (Brynjolfsson \& McAfee, 2014; Autor, 2015). These are increasingly non-routine analytical and cognitive tasks, such as deeplearning systems applied to medicine, or machines composing music. A crucial research and policy question is how these more advanced types of software and technologies are affecting firms' employment composition and the skill content of occupations.

To our knowledge, we are the first paper assessing the medium-run impacts of firms' adoption of advanced technologies on their demand for skills and jobs. We exploit a novel firm-level longitudinal survey for Chile across a six-year interval, 2007-2013, when the adoption of complex technology used in client management, production or administration and business software packages, is observed. We inquire whether the adoption of complex software is associated with labor reallocation within firms, across tasks using different skills. To date, the literature has mainly looked at the impacts of the automation process due to the use of computers (for example, Autor 
et al. (2003) and Autor \& Dorn (2013)). We argue that complex software, an advanced but intermediate technology between plain computers and full artificial intelligence, is more likely to be already replacing the use of routine-cognitive and analytical tasks, typically performed by more skilled workers.

Our findings show interesting patterns for Chile. First, in the medium run, complex software adoption is associated with a significant expansion of jobs among administrative and unskilled production and services workers and a reallocation of employment away from professionals and technical workers within firms. Second, consistent with these employment shifts, the adoption of complex software is linked to an increase in firms' use of routine and manual tasks, and a reduction in firms' use of abstract tasks, which are arguably performed by technology. Finally, our findings are driven by patterns of advanced technology adoption in sectors with relatively low-educated workforce and low-productivity, where most unskilled workers are employed. Altogether these findings suggest that the adoption of advanced technologies, such as complex software, have the potential to be inclusive for lower-skilled workers. Although our analysis is specific to Chile and to a particular type of technology, we believe it sheds new light on an important policy debate and begins to improve our understanding of the medium-term impacts of advanced technological adoption on changing patterns in the demand for skills.

We estimate a reduced-form specification relating the firm's adoption of complex software with the shares of different occupations in the firm's total employment and with an index capturing the skills content of different tasks across occupations, between 2007 and $2013 .{ }^{1}$ We face two empirical challenges. First, the firm's complex software adoption decision is likely jointly made with employment and skills choices based on unobserved firm characteristics (for example, managers ability). Second, complex software adoption depends on the firm's actual mix of 
occupations and skills. We mitigate these concerns in two ways: (i) exploiting the panel nature of the dataset to account for time-invariant firm unobservable characteristics via firm fixed effects and (ii) instrumenting firm-level adoption of complex software with a proxy for the sub-national degree of technological progress --the regional share of households with access to a computer-allowing that regional rollout to impact differentially firms depending on their sector's predetermined ICT intensity. ${ }^{2}$ We argue that firms located in regions with stronger computer demand and operating in ICT-intensive sectors are more likely to adopt complex software.

We exploit three micro datasets. First, we use a novel firm-level survey of formal private firms across all sizes and sectors in the Chilean economy, Encuesta Longitudinal de Empresas (henceforth ELE) for 2007 and 2013, that captures direct measures of technology adoption and the workforce's human capital. Second, we use Chilean data on the task content of each occupation from the 2014 Programme for the International Assessment of Adult Competencies survey (henceforth PIAAC). Third, we explore the Chilean national household survey (henceforth CASEN), for 2006 and 2013, to obtain information on sub-national ICT use.

This combination of data sources is unique. First, it allows us to assess impacts of complex software adoption across different occupations (managers, administrative workers, professionals and technical workers, and unskilled production and services workers) and across the task content of occupations, thus identifying which groups disproportionately benefit and which bear the cost of technology adoption. Second, Chile is a particularly interesting setting to study the impacts of ICT adoption on the demand for skills and jobs due to its high and persistent degree of income inequality. The Chilean economy is currently looking for sources of diversification and a more knowledge- and technologically-intensive growth model that can also be more inclusive (Dutz, Almeida \& Packard, 2018). 
We contribute to the literature in different ways. First, this paper is the first assessment of the link between advanced technology adoption and firm-level task content of occupations. Previous firm-level studies examine the impact of ICT measures such as IT capital stock/investment, computer adoption, broadband internet access, and number of IT workers on firms' employment, skills, and wages (Doms, Dunne \& Troske, 1997; Entorf, Gollac \& Kramarz, 1999; Caroli \& Van Reenen, 2001; Greenan \& Topiol-Bensaid, 2001; Bresnahan, Brynjolfsson \& Hitt, 2002; Bartel, Ichniowski \& Shaw , 2007; De Stefano, Kneller \& Timmis, 2014; Akerman, Gaarder \& Mogstad, 2015; and Gaggl \& Wright, 2016). To our knowledge only Bloom, Garicano, Sadun, and Van Reenen (2014) examine the impacts of complex software but focus on firms' organizational decisions rather than skill demand. We construct firm-level task indexes, weighing the task content of each occupation by its share in firm total employment. We divide the task content of occupations into abstract, routine, and manual categories following the task-based literature (see Autor \& Handel (2013) for the United States (U.S.) and Messina, Oviedo \& Pica (2016) for Latin America). Second, while previous literature focused on developed economies, we offer evidence for an emerging economy with high income inequality and some labor market polarization (Messina et al., 2016). Third, we exploit data on the task content of occupations specific to the country of study (Chile's PIAAC survey) whereas most previous studies exploit the U.S. task content of occupations assuming rankings are similar across countries.

The remainder of the paper proceeds as follows. Section 2 describes the data and summary statistics while Section 3 discusses the conceptual approach and testable hypotheses. Section 4 presents the econometric strategy. Section 5 discusses the main results. Section 6 focuses on heterogeneity and additional results and Section 7 concludes. 


\section{Data and Summary Statistics}

\subsection{Datasets and Definitions}

In the paper we exploit several datasets. First, we exploit a longitudinal firm-level survey representative of most economic activities in Chile, ELE, between 2007 and 2013. ${ }^{3}$ Technical details are provided in the online Supplementary Materials and all variables used are defined in Appendix Table A1.

ELE is a unique dataset to answer our research questions as it collects rich information on firm technology adoption, including use of computers and complex software. Complex software use captures the use of client management, production or administration and business software packages. This software can perform complex tasks within firms such as the planning of production levels (based on expected demand and stocks), inventory and order management, product pricing, management of marketing and clients, estimating production costs along the production process, controlling optimization of processes, and billing, accounting, finance, and human resources. Specific examples are Customer Relationship Management (CRM) software to manage business-customer relationships or Enterprise Resource Planning (ERP) software that integrates many functions, including inventory and order management, accounting, human resources, client management, onto a system to streamline processes and information across the entire firm. This variable markedly differs from more standard ICT measures in the literature (for example, computer use, internet access, or IT capital/investment) and we argue it likely impacts the firm's production process differently. Complex software adoption is largely managed by highly skilled workers and can lead complex routine but also non-routine analytical tasks. For instance, currently production software can perform the planning of production levels which was in the past carried out by professionals such as engineers. ${ }^{4}$ 
ELE also collects rich information about the firm's labor force including firm's total employment across four occupation categories - managers, administrative workers, professionals and technical workers, and unskilled production and services workers. Unfortunately, there is no additional information to generate occupational groupings more aligned with international occupations' classifications (such as ISCO). As control variables we use firm size, age, exporter status, foreign ownership, access to credit, degree of education, number of years of experience, and age of the manager. In some empirical exercises, we consider as firm outcomes: whether the firm is engaged in subcontracting activities and different types of training provided.

Second, we exploit the 2014 Chilean PIAAC survey on adult skills collected by the OECD which measures cognitive and workplace skills (for example, literacy, numeracy and problemsolving) across occupations. We use these to compute an index of the task content of occupations. ${ }^{5}$ Drawing on Acemoglu and Autor (2011) and Autor and Handel (2013), we define the task content of occupations using abstract, routine, and manual tasks categories. Abstract comprises abstract problem-solving and creative, organizational and managerial tasks, while routine involve codifiable tasks that follow explicit procedures, and manual comprises tasks that require physical adaptability. To define the task content of a specific occupation we identify in the PIAAC the set of questions closer to those used by other adult skills surveys (for example, DOT, PDII, O*NET or STEP surveys used by Autor et al. (2003), Autor \& Handel (2013), Di Carlo et al. (2016), and Messina et al. (2016)). The methodology used to construct the task content measures and the PIAAC questions used are detailed in the online Supplementary Materials.

We define the firm-level task indexes as a weighted average of the task content measures across all occupations, with weights given by the share of each occupation in the firm's total employment: 


$$
K_{j t}^{k}=\sum_{c=1}^{4} s h r_{j t c} * t a s k_{c}^{k}
$$

where $j$ designates a firm, $t$ a year, $c$ is one of the four occupations in ELE (managers, administrative workers, professionals and technical workers, and unskilled production and services workers), $k$ is a type of task (abstract, routine, and manual), task $k_{c}^{k}$ is the average of task content $k$ in occupation $c$, and $s h r_{j t c}$ is the share of occupation $c$ in firm total employment.

Panel A of Table 1 provides for each occupation, the average task content across firms in the sample $\left(\operatorname{tas}_{c}^{k}\right)$. Occupations with higher values are more intense in the indicated task. Panel B provides a schematic summary of the intensity of each task content measure for each occupation, showing whether the use of each task is above (+) or below (-) the average use of that task across all occupations. The shaded fields indicate the most important tasks for each occupation. The results show that the intensity of use of abstract and manual tasks is correlated with the skill intensity of occupations. Managerial, professionals, and technical occupations are more intensive in abstract tasks. Unskilled production and services occupations are more intensive in manual tasks. Routine tasks are more important for administrative and unskilled production and services occupations.

\section{TABLE 1}

Third, we exploit CASEN, a nationwide household survey for Chile, collected by the Ministry of Social Development which is representative across the 15 regions. We use data for 2006 and 2013 and construct regional measures of technological development/sophistication: the share of households with a computer in use and the share of households with at least one cell phone. This information is used to construct instrumental variables. We also construct measures of regional development: the share of urban households, the average number of years of education of members 
of the households, and the average household per capita income. These measures are used as control variables.

Finally, we exploit 2003 Chilean input-output matrix, published by Chile's Central Bank. For each 1-digit sector among 11, we calculate the share of ICT inputs --defined as telecommunication services-- in the total value of inputs used by the sector.

\subsection{Sample and Summary Statistics}

Using ELE, we construct our firm-level estimating sample: a balanced panel of 1,852 firms observed in 2007 and 2013. The balanced panel allows us to exploit changes in outcomes of interest over a six-year period. We conjecture this is a sufficiently long period to observe potential impacts following complex software adoption that could be hindered in the short-run when firms have more fixed factors of production. To obtain our firm-level estimating sample we consider firms with non-missing information on employment, software, and control variables included in our main specification (a total of 1,992 firms). We exclude outliers, defined as firms reporting very large changes in employment composition during the period (total of 140). ${ }^{6}$ The outliers likely have misreported information and their inclusion could bias our estimates. However, we will show our findings are not driven by this.

The sector and size composition of our final sample are shown in Table 2. Close to 40 per cent of firms operate in the wholesale and retail trade sector or in real estate and business activities, and less than a fifth operate in manufacturing. On average, 75 per cent of firms are micro or small whereas only 12 per cent of firms are large.

TABLE 2 
Table 3 reports summary statistics for our estimating sample. Panel A covers the main outcome variables. During the period, there was some firm downsizing from an average of 54 workers in 2007 to 44 workers in 2013. In this sample of predominantly micro and small firms, unskilled production and services workers are the major occupation, accounting on average for half of firm total employment and followed by professionals and technical workers accounting on average for a fifth of firm total employment. Between 2007 and 2013 the share of managers fell (from 14\% to $7 \%$ of total employment) and so did that of professionals and technical workers (from $23 \%$ to $19 \%$ of total employment). The share of unskilled production and services workers increased (from $46 \%$ to $58 \%$ of total employment), while that of administrative workers barely changed. On average firms in the sample make large use of manual and routine tasks and less use of abstract tasks. By construction, the observed changes in the firm-level task content of occupations indexes follow closely the changes in the shares of each occupation in firm total employment. Between 2007 and 2013, the abstract index declined whereas the routine and manual indexes increased. The large standard deviations of all these measures indicate a substantial degree of heterogeneity across firms in our main outcomes.

\section{TABLE 3}

Panel B of Table 3 covers the main independent variable: a (dummy) variable for whether the firm uses complex software. In our sample, 47 per cent of firms in Chile use complex software in 2007 and this percentage declines to 39 per cent in 2013. But for a different ICT variable --the use of computers-- the percentage of users increases from 81 per cent of firms in 2007 to 89 per cent in 2013. This evidence is in accordance with the increase in computer use by households across regions over the sample period (shown in the online Supplementary Materials). The reduction in the share of firms using complex software is consistent with firm downsizing over the period. This 
is perhaps the result of the global financial crisis, as small firms are less likely to use complex software (a finding shown in the online Supplementary Materials). Despite the crisis, firms continue to increase their use of computers likely for access to basic software, whose benefits exceed costs even in times of lower demand (whereas that may not be the case for complex software).$^{7}$

Figure 1 shows an important degree of variability in complex software use across sectors and regions in Chile and varying patterns between 2007 and 2013. The increase in complex software use over time is driven mainly by firms in services sectors but is widespread across several regions.

\section{FIGURE 1}

Since our main reduced-form equation will exploit changes in complex software use, we examine the prevalence of firms switching 'adoption' status and find it covers 25 per cent of firms in Chile between 2007 and 2013. ${ }^{8}$

Regarding variables with regional-level variation used as instruments in the instrumental variables specification, we show in the online Supplementary Materials that the regional percentage of households with a computer in use increased on average from 31 per cent in 2006 to close to 57 per cent in 2013 and all regions experienced an increase. The regional share of households with cell phones also increased substantially over time.

\section{Conceptual Framework and Testable Hypotheses}

Our testable hypotheses are as follows.

Professionals and technical workers: The impact of complex software adoption on firm employment of professionals and technical workers is ambiguous. On the one hand, we expect complex software to perform more abstract and routine tasks carried out by professionals and 
technical workers. This impact stands in contrast with the argument in the literature on automation of routine tasks performed by middle-educated workers through the adoption of technology (computer or internet) that complements skilled employment. For this reason, all else constant, we expect complex software use to potentially substitute for employment of professionals and technical workers. Brambilla (2018) proposes a theoretical model on digital technology adoption and jobs with heterogeneous firms that is flexible enough to allow for substitution between skilled employment and technology. On the other hand, skilled workers have the ability to interpret/draw upon the results produced by the complex software. Hence, we expect the degree of substitution of professionals and technical workers to be bounded by this consideration. Importantly, complex software use may have positive impacts on firm efficiency and output, which would increase the demand for any type of worker. Depending on which effect dominates (substitution or output expansion) there may be a reduction or an increase in the share of professionals and technical workers in firm total employment.

Unskilled production and services workers: If the adoption of complex software has an output expansion effect, then we should observe an increase in the demand for unskilled production and services workers and a possible increase in their share in total employment (depending on the relative increase for other occupations). Keeping the firm's output level fixed, an increase in the use of services workers related to software support and IT services is possible. In ELE, these types of occupations are included in the unskilled production and services workers category.

Managers and administrative workers: The impact of complex software adoption on firm employment of managers is likely to be negligible, while the impact on firm employment administrative workers is ambiguous. We do not expect the adoption of complex software to directly affect the demand for managers; furthermore, any output expansion effect may not 
translate into growth because managers are not directly involved in the production process. A negative impact on employment of administrative workers is possible as some tasks covered by complex software may enter in their domain, especially those covered by client management software. Concurrently, an expansion in firm output resulting from complex software adoption may increase the demand for administrative workers.

Task content of occupations: When a firm adopts complex software, the firm-level task indexes change mainly due to changes in the shares of the different occupations. Considering our previous hypotheses on employment shares, the change in the different task indexes due to complex software adoption is mostly ambiguous.

Sectoral heterogeneity in impacts: Our analysis covers different sectors, where the set of tasks performed by each occupation and the share of each occupation in total employment are different. We expect the elasticity of substitution between complex software and professionals and technical workers to vary across sectors due to these differences. In low-productivity sectors where the set of tasks carried out by professionals and technical workers and their share in total employment are small, skilled workers could be replaced by complex software. On the contrary, in highproductivity sectors where the set of professionals and technical workers' tasks and their share in total employment are large, complex software may complement skilled workers. Hence, the impact of complex software on different occupation shares and task indexes can differ across sectors.

\section{Econometric Strategy}

To test the hypotheses discussed in Section 4, we consider the following reduced-form specification relating complex software use to firm-level labor-related outcomes:

$$
Y_{j s r t}=\beta_{0}+\beta_{1} \text { software }_{j s r t}+\delta X_{j s r t}+I_{j}+I_{t}+\varepsilon_{j s r t}
$$


where $j$ is a firm, $s$ a sector, $r$ a region, $t$ a year, $Y$ is the main outcome (share of each occupation in firm total employment or firm-level task indexes), and software ssrt $_{j s}$ is a dummy variable for whether the firm uses complex software. The vector $X_{j s t}$ includes time-varying firm characteristics --size categories, age (in logs), exporter status, foreign ownership and credit constraints, age (in logs), years of experience (in logs) and indicators for the degree of education of the main manager, time-varying regional characteristics --average per capita household income (in logs), share of urban households, average number of years of education of the households (in logs), and timevarying province-sector number of computers used by firms, and region-specific time trends. In Equation (2), $I_{j}$ and $I_{t}$ are firm and year fixed effects, respectively, and $\varepsilon_{j s r t}$ is an error term.

Our parameter of interest is $\beta_{1}$ which captures the impact of complex software adoption on firm's occupational structure or task indexes. The OLS estimates of $\beta_{1}$ can be biased as firms likely make their software adoption and employment decisions jointly based on unobserved characteristics (for example, managerial quality). Controlling for firm fixed effects improves upon OLS estimates but there are still concerns to interpret $\beta_{1}$ as a causal impact of technology adoption on firm demand for skills. First, time-varying unobserved firm characteristics or shocks (for example, a performance boost) may affect the firm's choice to adopt complex software and drive the use of particular types of occupations and/or tasks. Second, the decision to adopt complex software may itself depend on the firm's mix of occupations and tasks.

We hope that the instrumental variables (IV) strategy we exploit mitigates these concerns. It is based on the sub-national adoption of a more aggregated measure of ICT: the regional share of households with a computer in use. We expect the use of computers by households at the subnational level to be positively correlated with the firm's adoption of complex software. This may happen as both firms and households benefit from reductions in prices of technology products and 
from exposure to newer technologies. Nevertheless, from the perspective of an individual firm, access to computers by households in its region is exogenous, that is, the firm does not influence the computer adoption decision of households. Our instrument exploits the interaction between the regional share of households with a computer in use (reg_computer $r$ ) and the Chilean sectoral ICT intensity $\left(I C T_{-}\right.$intens $\left.s_{s}\right)$ measured as of $2003 .{ }^{9}$ The rationale for the interaction term is that the degree of technological progress at the sub-national level can impact differentially firms depending on their sector's ICT intensity.

Additionally, we are concerned with three other identification challenges. First, the use of computers by households in a region may reflect the region's level of development which is likely correlated with firms' skills and employment choices. To mitigate this concern, our specification controls for time-varying variables capturing the regional level of development. Second, there may be time-varying unobserved regional shocks affecting both the use of computers by households and complex software adoption by firms such as variation in technology prices. To mitigate this concern, our specification includes region-specific time trends. Third, if firms invest in computers and other ICT technologies while investing in complex software there could be a concern with the exclusion restriction for our instrument as its impact on firm employment decisions would not operate just via the complex software adoption. To account for this possibility, our specification controls for other ICT usage at the region-sector level: the average number of computers used by firms in the region-sector each year.

Our first-stage specification is thus given by:

$$
\begin{aligned}
\text { software }_{j s r t} & =\delta_{0}+\delta_{1}\left(\text { reg_computer }_{r t} * I C T_{-} \text {intens }_{s}\right)+\pi X_{j s r t}+I_{j}+I_{t}+I_{r} * T_{t} \\
& +u_{j s t}
\end{aligned}
$$


where $I_{r}$ are region indicators and $T_{t}$ a linear time trend, $u_{j s r t}$ an independent and identically distributed (i.i.d.) error term, and all other variables are defined above.

The second-stage specification is given by:

$$
Y_{j s r t}=\beta_{0}+\beta_{1} \text { softwar }_{\text {jsrt }}+\delta X_{j s r t}+I_{j}+I_{t}+I_{r} * T_{t}+\epsilon_{j s r t}
$$

where softwar $e_{\text {Jsrt }}$ is estimated from the first-stage (in a two-stage least squares framework) and the error $\epsilon_{j s r t}$ is an i.i.d. error term. Equation (4) estimates robust correlations between complex software adoption and firm labor outcomes exploiting variation within firms over time, rather than cross-sectional variation across very different firms. Inference is based on Huber-White standard errors robust to heteroscedasticity, clustered at the region-sector level to account for the more aggregate degree of variability of the instrument (Moulton, 1990).

\section{Impact of Complex Software Adoption on Employment Composition and Task Content of Occupations}

Panel A of Table 4 reports OLS estimates of Equation (3), Panels B and C report second-stage estimates of Equation (4) relating instrumented firm adoption of complex software with skill composition of firm employment (Panel B) and firm task indexes (Panel C). ${ }^{10}$

Panel A shows a positive and statistically significant correlation between a firm's adoption of complex software and the share of households with a computer in use interacted with the firm's sector ICT intensity. Despite the decrease in software use over time in some regions and sectors in Chile (Figure 1), the correlation between complex software adoption and our proposed instrument is positive and strong. When the use of technology increases at the region-sector level, the firm's adoption of complex software also increases significantly for firms in that region-sector. With a fixed sectoral ICT intensity, for each percentage point increase in the regional share of households 
with a computer in use, the share of firms adopting complex software increases by approximately 4 percentage points. The reported p-value for the Sanderson and Windmeijer (2016) underidentification test suggests that the proposed instrument is valid. The F-statistic is close to 10 , the Staiger and Stock (1997) rule for rejection of the hypothesis of weak instruments with one endogenous variable.

\section{TABLE 4}

The results in Panels B and C show that complex software adoption is negatively and significantly associated with the share of professionals and technical workers and positively and significantly associated with the share of unskilled production and services workers in firms' total employment in Chile. Specifically, complex software adoption by a firm reduces the share of professionals and technical workers by 58 percentage points and increases the share of unskilled production workers by 57 percentage points. Panel B also shows that complex software adoption decreases the share of managers and increases the share of administrative workers, but those effects are statistically insignificant.

Panel $\mathrm{C}$ shows that complex software adoption is significantly negatively linked to the abstract task index and significantly positively linked to the routine and manual task indexes. These correlations follow strongly the correlations with the different occupations' shares, which are the weights used to construct the task indexes.

The findings in Table 4 are robust to: the use of an alternative methodology to compute firmlevel task indexes following Autor and Handel (2013), measuring the task content of occupations separately across sectors, the use of an alternative instrument for firm complex software use (the share of households in the region with at least one cell phone), the use of no cross-sectional sampling weights, the inclusion of 140 'outlier firms' (exhibiting very large changes in 
employment composition between 2007 and 2013), the use of region and sector fixed effects (ignoring the panel structure of the data), and the control for sector-specific time trends related for instance to the commodity price boom experienced by Chile over the period, as shown in the online Supplementary Materials.

One could think of three additional threats to our identification strategy. First, the growing use of computers by households in a region may change the quality of the available workforce because workers become more proficient at using computers. This change could influence firms' labor demand. Our prior is that the growing use of computers in a region does not necessarily improve workers' aptitudes to handle complex software. Nevertheless, the region-specific time trends included in the reduced-form account for changes in the quality of a region's workforce over time. Second, firms in ICT-intensive industries could relocate to take advantage of differential reductions in technology prices or differential quality of the workforce (via the first threat) across regions. However, in our panel there is no sub-national relocation of firms over time. Third, the growing demand for computers by households in a region could directly impact output and employment of firms involved in the production or sale of computers. Hence, we exclude from our sample two sectors - IT producers (manufacturing) and IT sellers (wholesale and retail trade) - but results are maintained (see the online Supplementary Materials).

Our findings indicate that complex software adoption by Chilean firms, which we hypothesized is a technology that automates complex routine and abstract tasks performed by high-educated workers, is associated with firm changes in their occupational structure in the medium term in a way that decreases the share of some of the workers performing abstract and routine tasks mainly (professionals and technical workers) and increases the share of some of the workers performing manual tasks primarily (unskilled production and services workers). Our interpretation for these 
findings is that more sophisticated software technologies are affecting labor markets differently than previous computerization and automation of routine tasks carried out by middle-educated workers. Complex software has a skill component and is thus performing some tasks previously carried out by high-educated workers (substitution effect). However, high-educated workers have the cognitive abilities to analyze and interpret the information coming out from the software (complementarity effect). Our results suggest that, in Chile, the substitution effect is on average offsetting any complementarity effect for professionals and technical workers. The increase in the share of unskilled production and services workers in total employment can be potentially explained by an expansion in firms' output and employment, with the demand for unskilled production and services workers increasing at a significantly higher pace than the demand for professionals and technical workers due to complex software adoption. We provide evidence for this potential explanation in Table 5 where we examine whether firms change the actual levels of employment of different occupations as a result of complex software adoption. ${ }^{11}$ Complex software adoption increases significantly the level of employment of unskilled production and services workers and administrative workers (the latter at a $10 \%$ confidence level), with no significant change in the level of employment of managers and professionals and technical workers. These findings suggest that firms adopting complex software are expanding their total employment, but each occupation adjusts at a different rate. ${ }^{12}$ The insignificant changes in the demand for professionals and technical workers that accompany the significant increase in the demand for unskilled production and services workers and administrative workers can be explained by the adoption of the complex software allowing the automation of some high-skilled tasks. However, it is interesting to highlight that there is no statistically significant reduction in the 
demand for professionals and technical workers, suggesting that this employment category still has a role in the production process.

TABLE 5

\section{Heterogeneity of Impact of Complex Software Adoption}

This section examines whether complex software adoption has differential impacts on firm task indexes and employment shares of different occupations depending on firm size and sector educational composition. We estimate a specification similar to Equation (4) where the complex software variable is interacted with two separate indicator variables for firms with and without a given characteristic. Table 6 reports the second-stage estimates allowing the impacts to differ by firm size (as of 2007) and sector education (as of 2007), respectively. ${ }^{13}$

TABLE 6

The estimates show that our main findings (Table 4) are explained by the behavior of small, medium and large firms (all included in the 'not-micro' firms category). The impacts on micro firms are insignificant. For non-micro firms there is also a significant increase in the share of administrative workers in total employment. It is not surprising that complex software adoption does not impact labor demand by micro firms as such type of software is unlikely to be important for them (outside of high-tech sectors). Micro firms typically do not have intensive computation or large database management needs, they employ relatively simple management and production techniques. Complex software would not be cost-effective for them nor have large employment effects.

Table 6 also shows that the reduction in the share of professionals and technical workers with complex software adoption happens mainly in sectors with a low-educated workforce. The impact 
for firms in sectors with a high-educated workforce goes in the opposite direction but is statistically insignificant. For the share of unskilled production and services workers and the task indexes, we cannot identify a significant differential impact across sectors, but our findings in Section 5 are verified for sectors with a low-educated workforce. If the workforce education level is, at least partially, a proxy for the productivity of the sector, then these results confirm our hypothesis of substitutability between professionals and technical production workers and complex software in low-productivity sectors and possible complementarity in high-productivity sectors.

We also analyze whether complex software adoption changes firms' investment in training. The online Supplementary Materials shows that firms adopting complex software do not significantly change the training provided to workers, but they increase the likelihood of the manager receiving ICT-specific training.

\section{Conclusion}

A large body of evidence documents that labor markets are becoming more polarized in developed countries, with employment and earnings shifting from middle-skilled jobs to both high-skilled and low-skilled jobs. This has raised concerns on the extent to which technology adoption could automate routine tasks and potentially displace middle-skilled occupations. Additional concerns arise as more advanced technologies, used by more educated workers, are increasingly replacing also cognitive and analytical tasks. At the same time, many economists argue that technology adoption will, at least in the medium run, significantly increase firm productivity and, under certain policy conditions, lead to job expansion. The overall impacts of technology adoption on employment and on the skill composition of occupations remain therefore an empirical question. 
We are the first paper estimating, in the medium term, the impact of the adoption of more sophisticated technologies on employment and skills composition of jobs within firms. We estimate a reduced-form specification relating complex software adoption with firm-level measures of skills composition. We mitigate potential endogeneity concerns by exploiting changes in the firm's technology adoption between 2007 and 2013 and instrumenting that adoption with a measure of regional propensity for technological progress, whose impact is allowed to differ across sectors. Our prior is that firms are more likely to adopt complex technologies in sectors with an initially higher ICT intensity and when the household use of computers is higher in the region where they are located.

Our main findings show interesting patterns. First, in the medium run, complex software adoption is leading to a significant expansion of jobs among administrative workers and unskilled production and services workers. Furthermore, the adoption of complex software reallocates employment within firms away from professionals and technical workers. Second, consistent with these employment shifts, the adoption of complex software is linked to an increase in firms' use of routine and manual tasks, and a reduction in firms' use of abstract tasks, which are now arguably being performed by technology. Finally, we show that our findings are mainly driven by the adoption of advanced technology in sectors with relatively low-education and low-productivity, where most of the unskilled workers are employed. These findings have important policy implications. First, they are consistent with the view that the adoption of advanced software can in the medium-term lead to 'inclusive' employment expansions as firms overcome any short-term rigidities. Second, education and training systems can substantively promote the adoption of more advanced technology, if policies support the development of digital skills, especially among employers. 


\section{References}

Acemoglu, D., \& Autor, D. (2011). Skills, Tasks and Technologies: Implications for Employment and Earnings. In Orley Ashenfelter and David Card (eds.) Handbook of Labor Economics, Vol. 4, Part B, 1043-1171. Amsterdam: Elsevier.

Akerman, A., Gaarder, I., \& Mogstad, M. (2015). The Skill Complementarity of Broadband Internet. The Quarterly Journal of Economics, 130(4), 1781-1824.

Alvarez, R. (2016). The Impact of R\&D and ICT Investment on Innovation and Productivity in Chilean Firms. Serie de Documentos de Trabajo 428. Universidad de Chile, Chile.

Autor, D. (2014). Skills, Education, and the Rise of Earnings Inequality among the 'Other 99 Percent'. Science, 344(6186), 843-851.

Autor, D. (2015). Why Are There Still So Many Jobs? The History and Future of Workplace Automation. Journal of Economic Perspectives, 29(3), 3-30.

Autor, D., \& Dorn, D. (2013). The Growth of Low-Skill Service Jobs and the Polarization of the US Labor Market. The American Economic Review, 103(5), 1553-1597.

Autor, D., \& Handel, M. J. (2013). Putting Tasks to the Test: Human Capital, Job Tasks, and Wages. Journal of Labor Economics, 31(2), 59-96.

Autor, D., Levy, F., \& Murnane, R. (2003). The Skill Content of Recent Technological Change: An Empirical Exploration. Quarterly Journal of Economics, 118(4), 1279-1333.

Bartel, A.P., Ichniowski, C., \& Shaw, K.L. (2007). How Does Information Technology Really Affect Productivity? Plant-Level Comparisons of Product Innovation, Process Improvement and Worker Skills. The Quarterly Journal of Economics, 122(4), 1721-1758.

Bloom, N., Garicano, L., Sadun, R., \& Van Reenen, J. (2014). The Distinct Effects of Information Technology and Communication Technology on Firm Organization. Management Science, 60(12), 2859-2885.

Brambilla, I. (2018). Digital Technology Adoption and Jobs: A Model of Firm Heterogeneity. Policy Research Working Paper 8326, The World Bank, Washington, DC.

Bresnahan, T.F., Brynjolfsson, E., \& Hitt, L.M. (2002). Information Technology, Workplace

Organization, and the Demand for Skilled Labor: Firm Level Evidence. The Quarterly Journal of Economics, 117(1), 339-376.

Brynjolfsson, E., \& McAfee, A. (2014). The Second Machine Age: Work, Progress, and Prosperity in a Time of Brilliant Technologies. New York, NY: W.W. Norton \& Company. Caroli, E., \& Van Reenen., J. (2001). Skill-Biased Organizational Change? Evidence from A Panel of British and French Establishments. The Quarterly Journal of Economics, 116(4), 14491492.

Cirillo, V. (2016). Pattern of Innovation and Wage Distribution. Do Innovative Firms Pay Higher Wages? Evidence from Chile. Eurasian Business Review, 4, 181-206.

Cruces G., Fields, G., Jaume, D., \& Viollaz, M. (2017). The Growth-Employment-Poverty Nexus in Latin America. Oxford, UK: Oxford University Press.

De Stefano T., Kneller, R., \& Timmis, J. (2014). The (Fuzzy) Digital Divide: The Effect of Broadband Internet Use on UK Firm Performance. Discussion papers, School of Economics, University of Nottingham, Nottingham, UK.

Di Carlo, E., Lo Bello, S., Monroy-Taborda, S., Oviedo, A.M., Sanchez-Puerta, M.L., \& Santos, I. (2016). The Skill Content of Occupations across Low and Middle Income Countries: Evidence from Harmonized Data. IZA Discussion Paper 10224, IZA Institute of Labor Economics. 
Doms, M., Dunne, T., \& Troske, K. (1997). Workers, Wages, and Technology. The Quarterly Journal of Economics, 112(1), 253-290.

Dutz, M., Almeida, R., Packard, T. (2018). The Jobs of Tomorrow: Technology, Productivity, and Prosperity in Latin America and the Caribbean. Directions in Development. Washington, DC: World Bank.

Engelstätter, B., \& Sarbu, M. (2013). Does Enterprise Software Matter for Service Innovation? Standardization versus Customization. Economics of Innovation and New Technology, 22(4), 412-429.

Frey, C., \& Osborne, M. (2013). The Future Of Employment: How Susceptible Are Jobs To Computerisation?. Working Paper, Oxford Martin School, University of Oxford, UK. Gaggl, P., \& Wright, G. (2016). A Short-Run View of What Computers Do: Evidence from a U.K. Tax Incentive. American Economic Journal: Applied Economics. Forthcoming. Greenan, N., \& Topiol-Bensaid, A. (2001). Information Technology and Research and Development Impacts on Productivity and Skills: Looking for Correlations on French Firm Level Data. In Pohjola, Matti (ed.) Information Technology, Productivity, and Economic Growth: International Evidence and Implications for Economic Development. UNU/WIDER Studies in Development Economics. Oxford and New York: Oxford University Press.

Entorf, H., Gollac, M., \& Kramarz, F. (1999). New Technologies, Wages, and Worker Selection. Journal of Labor Economics, 17(3), 464-491.

Iacovone, L., Pereira-Lopez, M., \& Schiffbauer, M. (2016). Competition Makes IT Better. Evidence on When Firms Use IT More Effectively. Policy Research Working Paper 7638. The World Bank, Washington, DC.

Messina, J., Oviedo, A.M., \& Pica, G. (2016). Job Polarization in Latin America. Mimeo, The World Bank, Washington, DC.

Moulton, B. (1990). An Illustration of a Pitfall in Estimating the Effects of Aggregate Variables on Micro Units. Review of Economics and Statistics, 72(2), 334-338.

Muendler, M. (2017). Trade, Technology, and Prosperity: An Account of Evidence from a Labor-market Perspective. Staff Working Paper ERSD-2017-15 World trade Organization, Geneva, Switzerland.

Sanderson, E., \& Windmeijer, F. (2016). A Weak Instrument F-Test in Linear IV Models with Multiple Endogenous Variables. Journal of Econometrics, 190(2), 212-221.

Santoleri, P. (2015). Diversity and Intensity of Information and Communication Technologies Use and Product Innovation: Evidence from Chilean Micro-Data. Economics of Innovation and New Technology, 24(6), 550-568.

SEDLAC. (2017). Socio-Economic Database for Latin America and the Caribbean (CEDLAS and The World Bank). Retrieved from http://sedlac.econo.unlp.edu.ar/esp/.

Staiger, D., \& Stock, J. (1997). Instrumental Variables Regression with Weak Instruments. Econometrica, 65(3), 557-586.

World Bank. (2016). World Development Report: Digital Dividends, The World Bank, Washington D.C. 
Table 1. Task Content Measures based on the PIAAC Survey by Occupation in the ELE Survey Panel A. Values of Task Content Measures Following Methodology of Acemoglu and Autor (2011)

\begin{tabular}{lccc}
\hline & Abstract & Routine & Manual \\
\hline Managers & & & -1.137 \\
Adminis trative workers & 1.081 & -1.320 & 0.274 \\
Professionals and technical workers & -0.127 & 0.556 & -0.362 \\
Unskilled production and services workers & -1.302 & 0.955 & 1.225 \\
\hline Panel B. Comparison to Average Task Content across All Occupations \\
\hline Managers & Abstract & Routine & Manual \\
\hline Administrative workers & + & - & - \\
Professionals and technical workers & - & + & + \\
Unskilled production and services workers & + & - & - \\
\hline \hline
\end{tabular}

Source: Authors' calculations based on ELE's 2007 and 2013 waves and 2014 Chile PIAAC.

Notes: The task content of occupations measures are constructed as described in the online Supplementary Materials. Panel B shows whether each task content measure of a given occupation in ELE is above (+) or below (-) the average of that task content across all occupations. Shaded fields indicate the most important tasks content for each occupation.

Table 2. Sectoral and Size Composition of the ELE Panel Sample
\[ \begin{array}{lc}\text { Size } & 41.74 \\ \text { Micro } & 33.86 \\ \text { Small } & 12.09 \\ \text { Medium } & 12.30 \\ \text { Large } & \\ & \\ \text { Sector } & 11.3 \\ \text { Agriculture, hunting, fishing and forestry } & 0.9 \\ \text { Mining and quarrying } & 16.2 \\ \text { Manufacturing } & 0.2 \\ \text { Electricity, gas and water supply } & 10.2 \\ \text { Construction } & 25.4 \\ \text { Wholesale and retail trade } & 5.8 \\ \text { Hotels and restaurants } & 7.8 \\ \text { Transport, storage and communications } & 0.9 \\ \text { Financial intermediation } & 14.5 \\ \text { Real estate and business activities } & 6.8 \\ \text { Other service activities } & \end{array} \]

Source: Authors' calculations based on ELE's 2007 and 2013 waves.

Notes: Size categories are defined in Table A1. 
Table 3. Summary Statistics on Employment-Related Outcome Variables, ICT Use Variables and Firm Characteristics

\begin{tabular}{|c|c|c|c|c|}
\hline & \multicolumn{2}{|c|}{2007} & \multicolumn{2}{|c|}{2013} \\
\hline & Mean & St. Dev. & Mean & St. Dev. \\
\hline \multicolumn{5}{|c|}{ Panel A: Employment-Related and Task-Related Variables at Firm Level } \\
\hline Total employment & 53.66 & 280.39 & 43.59 & 443.33 \\
\hline \multicolumn{5}{|l|}{ Shares in total employment of: } \\
\hline Managers & 0.14 & 0.26 & 0.07 & 0.16 \\
\hline Administ. workers & 0.17 & 0.25 & 0.16 & 0.23 \\
\hline Professionals \& technical workers & 0.23 & 0.32 & 0.19 & 0.33 \\
\hline Unskilled prod. \& services workers & 0.46 & 0.42 & 0.58 & 0.39 \\
\hline \multicolumn{5}{|l|}{ Task indexes } \\
\hline Abstract task index & -0.38 & 0.76 & -0.64 & 0.65 \\
\hline Routine task index & 0.30 & 0.64 & 0.52 & 0.50 \\
\hline Manual task index & 0.36 & 0.73 & 0.61 & 0.62 \\
\hline \multicolumn{5}{|l|}{ Training and outsourcing variables } \\
\hline Worker training & 0.30 & 0.46 & 0.12 & 0.32 \\
\hline Manager training & 0.25 & 0.43 & 0.06 & 0.24 \\
\hline Manager training on ICT & 0.02 & 0.14 & 0.00 & 0.06 \\
\hline Outsourcing & 0.10 & 0.30 & 0.05 & 0.22 \\
\hline \multicolumn{5}{|c|}{ Panel B: ICT Use at Firm Level } \\
\hline Computer use & 0.81 & 0.40 & 0.89 & 0.31 \\
\hline Complex software use & 0.47 & 0.50 & 0.39 & 0.49 \\
\hline \multicolumn{5}{|c|}{ Panel C: Firm Characteristics } \\
\hline Firm age & 11.80 & 10.21 & 17.79 & 9.87 \\
\hline Exporter & 0.06 & 0.24 & 0.04 & 0.19 \\
\hline Foreign-owned & 0.02 & 0.14 & 0.01 & 0.09 \\
\hline Credit-constrained & 0.05 & 0.21 & 0.03 & 0.16 \\
\hline Manager age & 50.85 & 11.22 & 56.55 & 12.30 \\
\hline Manager years of experience & 21.32 & 12.15 & 24.78 & 13.09 \\
\hline Manager with second. education & 0.33 & 0.47 & 0.37 & 0.48 \\
\hline Manager with college education & 0.63 & 0.48 & 0.58 & 0.49 \\
\hline Number of firms & \multicolumn{2}{|c|}{1,852} & \multicolumn{2}{|c|}{1,852} \\
\hline
\end{tabular}

Source: Authors' calculations based on ELE's 2007 and 2013 waves and 2014 Chile PIAAC.

Note: Statistics were obtained using ELE sampling weights. 
Table 4. Firm Complex Software Adoption, Employment Composition and Task Indexes

\begin{tabular}{|c|c|c|c|c|}
\hline \multirow[t]{2}{*}{ Dependent variable: } & \multicolumn{4}{|c|}{ Panel A: First-stage - Firm complex software use } \\
\hline & (1) & & & \\
\hline \multirow{2}{*}{$\begin{array}{l}\text { Share of hhlds with computer * } \\
\text { sector ICT intensity }\end{array}$} & 4.541 & & & \\
\hline & {$[1.409]^{* * *}$} & & & \\
\hline$P$-value of underid. test & 0.0012 & & & \\
\hline F stat & 10.39 & & & \\
\hline \multirow[t]{3}{*}{ Dependent variable: } & \multicolumn{4}{|c|}{ Panel B: Second-stage - Firm employment shares } \\
\hline & Managers & $\begin{array}{c}\text { Professionals } \\
\& \text { technical } \\
\text { workers }\end{array}$ & $\begin{array}{l}\text { Administ. } \\
\text { workers }\end{array}$ & $\begin{array}{c}\text { Unskilled } \\
\text { production \& } \\
\text { services } \\
\text { workers }\end{array}$ \\
\hline & (1) & (2) & (3) & $(4)$ \\
\hline \multirow[t]{2}{*}{ Firm complex software use } & -0.270 & -0.583 & 0.282 & 0.571 \\
\hline & [0.228] & {$[0.258]^{\star *}$} & [0.209] & {$[0.256]^{\star *}$} \\
\hline \multirow[t]{2}{*}{ Dependent variable: } & \multicolumn{4}{|c|}{ Panel C: Second-Stage - Firm task indexes } \\
\hline & $\begin{array}{l}\text { Abstract } \\
\text { (1) }\end{array}$ & $\begin{array}{c}\text { Routine } \\
(2)\end{array}$ & $\begin{array}{c}\text { Manual } \\
(3)\end{array}$ & \\
\hline \multirow[t]{2}{*}{ Firm complex software use } & -1.273 & 1.170 & 1.294 & \\
\hline & {$[0.506]^{* *}$} & {$[0.473]^{* *}$} & {$[0.499]^{* * *}$} & \\
\hline Observations & 3,704 & 3,704 & 3,704 & \\
\hline
\end{tabular}

Source: Authors' calculations based on ELE's 2007 and 2013 waves and 2014 Chile PIAAC.

Notes: Robust standard errors in brackets clustered by region-sector. $* * *, * *$, and * indicate significance at 1,5 , and 10 per cent confidence levels, respectively. Panel A reports the estimates of the first-stage given by Equation (3). Panels B and C report the 2SLS estimates of the second-stage given by Equation (4). All regressions control for firm and year fixed effects and include time-varying firm characteristics (size categories, age (in logs), exporter, foreignowned, and credit constrained indicators, age (in logs), number of years of experience (in logs) and indicators for the degree of education of the main manager), time-varying region characteristics (average per capita household income (in logs), share of urban households, and average number of years of education of households (in logs)), number of computers used by firms in the region-sector, as well as region-specific time trends. In Panel A, the underidentification test is based on Sanderson and Windmeijer (2016).

Table 5. Firm Complex Software Adoption and Firm Levels of Employment across Occupations

\begin{tabular}{|c|c|c|c|c|}
\hline \multirow[t]{3}{*}{ Dependent variable: } & \multicolumn{4}{|c|}{ Log of employment } \\
\hline & Managers & $\begin{array}{c}\text { Professionals } \\
\& \text { technical } \\
\text { workers }\end{array}$ & $\begin{array}{c}\text { Administ. } \\
\text { workers }\end{array}$ & $\begin{array}{c}\text { Unskilled } \\
\text { production \& } \\
\text { services } \\
\text { workers }\end{array}$ \\
\hline & (1) & (2) & (3) & (4) \\
\hline Firm complex software use & $\begin{array}{l}-0.764 \\
{[0.481]}\end{array}$ & $\begin{array}{l}-1.243 \\
{[0.869]}\end{array}$ & $\begin{array}{c}1.462 \\
{[0.814]^{*}}\end{array}$ & $\begin{array}{c}2.799 \\
{[1.136]^{\star *}}\end{array}$ \\
\hline Observations & 3,704 & 3,704 & 3,704 & 3,704 \\
\hline
\end{tabular}

Source: Authors' calculations based on ELE's 2007 and 2013 waves and 2014 Chile PIAAC.

Notes: Robust standard errors in brackets clustered by region-sector. ***,**, and * indicate significance at 1,5 , and 10 per cent confidence levels, respectively. All regressions control for firm and year fixed effects and include timevarying firm characteristics (size categories, age (in logs), exporter, foreign-owned, and credit constrained indicators, age (in logs), number of years of experience (in logs) and indicators for the degree of education of the main manager), time-varying region characteristics (average per capita household income (in logs), share of urban households, and average number of years of education of households (in logs)), number of computers used by firms in the regionsector, as well as region-specific time trends. 
Table 6. Heterogeneity of Impact of Firm Complex Software Adoption on Employment Composition and Task Indexes across Firm Size and Sector's Workforce Education Level

\begin{tabular}{|c|c|c|c|c|c|c|c|}
\hline \multirow[t]{2}{*}{ Dependent variable: } & \multicolumn{4}{|c|}{ Panel A: Second-stage - Firm employment shares } & \multicolumn{3}{|c|}{ Panel B: Second-Stage - Firm task indexes } \\
\hline & $\begin{array}{c}\text { Managers } \\
\text { (1) }\end{array}$ & $\begin{array}{c}\text { Professionals } \\
\& \text { technical } \\
\text { workers } \\
(2) \\
\end{array}$ & $\begin{array}{c}\text { Administ. } \\
\text { workers } \\
(3)\end{array}$ & $\begin{array}{c}\text { Unskilled } \\
\text { production \& } \\
\text { services } \\
\text { workers } \\
(4) \\
\end{array}$ & $\begin{array}{c}\text { Abstract } \\
\text { (5) }\end{array}$ & $\begin{array}{c}\text { Routine } \\
(6) \\
\end{array}$ & $\begin{array}{c}\text { Manual } \\
(7)\end{array}$ \\
\hline \multicolumn{8}{|l|}{ By firm size } \\
\hline $\begin{array}{l}\text { Firm complex software use } \\
{ }^{*} \text { Micro firm }\end{array}$ & $\begin{array}{l}-0.202 \\
{[0.375]}\end{array}$ & $\begin{array}{l}-0.0548 \\
{[0.540]}\end{array}$ & $\begin{array}{l}-0.0843 \\
{[0.316]}\end{array}$ & $\begin{array}{c}0.341 \\
{[0.422]}\end{array}$ & $\begin{array}{l}-0.671 \\
{[0.828]}\end{array}$ & $\begin{array}{c}0.557 \\
{[0.735]}\end{array}$ & $\begin{array}{c}0.645 \\
{[0.809]}\end{array}$ \\
\hline $\begin{array}{l}\text { Firm complex software use } \\
{ }^{*} \text { Non-micro firm }\end{array}$ & $\begin{array}{l}-0.320 \\
{[0.200]}\end{array}$ & $\begin{array}{c}-0.971 \\
{[0.385]^{\star *}}\end{array}$ & $\begin{array}{c}0.551 \\
{[0.257]^{\star *}}\end{array}$ & $\begin{array}{c}0.739 \\
{[0.369]^{\star *}}\end{array}$ & $\begin{array}{c}-1.715 \\
{[0.672]^{\star *}}\end{array}$ & $\begin{array}{c}1.620 \\
{[0.564]^{\star \star \star}}\end{array}$ & $\begin{array}{c}1.771 \\
{[0.658]^{\star \star *}}\end{array}$ \\
\hline P-value for test of equality of coefficients & 0.753 & 0.095 & 0.120 & 0.452 & 0.284 & 0.198 & 0.232 \\
\hline \multicolumn{8}{|l|}{ By educational level of the workforce } \\
\hline $\begin{array}{l}\text { Firm complex software use } \\
{ }^{*} \text { High-educated workforce }\end{array}$ & $\begin{array}{c}-2.430 \\
{[1.422]^{*}}\end{array}$ & $\begin{array}{c}1.594 \\
{[1.112]}\end{array}$ & $\begin{array}{c}0.665 \\
{[0.479]}\end{array}$ & $\begin{array}{c}0.170 \\
{[0.425]}\end{array}$ & $\begin{array}{l}-2.380 \\
{[1.557]}\end{array}$ & $\begin{array}{c}3.435 \\
{[2.019]^{*}}\end{array}$ & $\begin{array}{c}2.577 \\
{[1.624]}\end{array}$ \\
\hline $\begin{array}{l}\text { Firm complex software use } \\
\quad{ }^{*} \text { Low-educated workforce }\end{array}$ & $\begin{array}{l}-0.258 \\
{[0.222]}\end{array}$ & $\begin{array}{c}-0.595 \\
{[0.256]^{* *}}\end{array}$ & $\begin{array}{c}0.280 \\
{[0.210]}\end{array}$ & $\begin{array}{c}0.573 \\
{[0.258]^{* *}}\end{array}$ & $\begin{array}{c}-1.267 \\
{[0.506]^{* *}}\end{array}$ & $\begin{array}{c}1.157 \\
{[0.469]^{* *}}\end{array}$ & $\begin{array}{c}1.288 \\
{[0.498]^{\star * *}}\end{array}$ \\
\hline P-value for test of equality of coefficients & 0.134 & 0.041 & 0.443 & 0.428 & 0.511 & 0.284 & 0.463 \\
\hline Observations & 3,704 & 3,704 & 3,704 & 3,704 & 3,704 & 3,704 & 3,704 \\
\hline
\end{tabular}

Source: Authors' calculations based on ELE's 2007 and 2013 waves and 2014 Chile PIAAC.

Notes: Robust standard errors in brackets clustered by region-sector. ***,**, and * indicate significance at 1,5 , and 10 per cent confidence levels, respectively. All regressions control for firm and year fixed effects and include time-varying firm characteristics (size categories, age (in logs), exporter, foreign-owned, and credit constrained indicators, age (in logs), number of years of experience (in logs) and indicators for the degree of education of the main manager), time-varying region characteristics (average per capita household income (in logs), share of urban households, and average number of years of education of households (in logs)), number of computers used by firms in the region-sector, as well as region-specific time trends. Micro firms are defined in Table A1 in the Appendix and non-micro firms include small, medium and large firms. High-educated sectors are those having at least $50 \%$ of their workforce with college education in 2007. 
Figure 1. Complex Software Use across Regions and Sectors
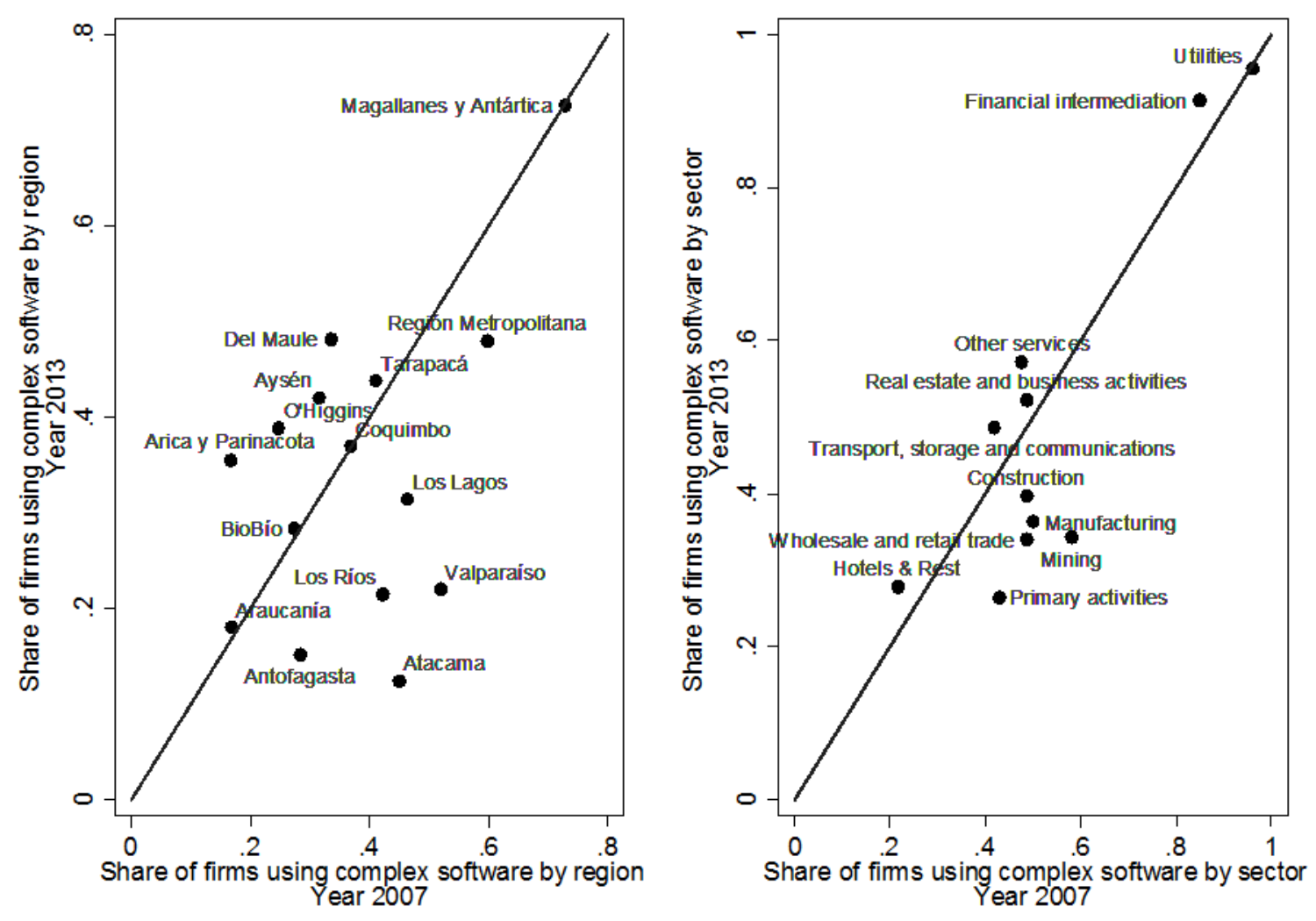

Source: ELE's 2007 and 2013 waves.

Note: The shares were obtained using ELE sampling weights. 


\section{Appendix}

\section{Table A1. Definition of Variables taken from ELE}

\section{Variables}

Managers

Administrative workers

Administrative workers

Professionals and technical workers

\section{Definition}

Owners and partners (working in the firm without fixed remuneration 15 hours or more per week), managers, sub-managers and other salaried workers whose functions are to administer, plan, organize, control and direct the activities of the firm.

Adminis trative workers are defined as office and adminis trative workers, employees that deal directly with the public (excep sales personnel) as well as any personnel in charge of accounting, statistical data entry and processing, secretariat, clerk service, and customer support.

Professionals and technicians working directly related with the firm's main activity and with a high degree of competency inside the firm. Their activities cover analysis and research, application of concepts, methods and techniques in the production or extraction of products, supervision of other workers, provision of legal services, social services, economic and commercial services.

Unskilled production and services Non-technical personnel in charge of executing simple and routine tasks directly related to the firm's main activity which require workers mainly the use of manual tools and some physical effort. Services and sales workers are also included in this category.

\begin{tabular}{|c|c|}
\hline Abstract task index & $\begin{array}{l}\text { Weighted average of an abstract task measure for each employment category obtained from the PIAAC survey. Weights are } \\
\text { defined as the share of each employment category in firm total employment. }\end{array}$ \\
\hline Routine task index & $\begin{array}{l}\text { Weighted average of a routine task measure for each employment category obtained from PIAAC survey. Weights are defined as } \\
\text { the share of each employment category in firm total employment. }\end{array}$ \\
\hline Manual task index & $\begin{array}{l}\text { Weighted average of a manual task measure for each employment category obtained from PIAAC survey. Weights are defined as } \\
\text { the share of each employment category in firm total employment. }\end{array}$ \\
\hline Worker training & Indicator variable for whether workers (other than the manager) participated in training courses during the survey year. \\
\hline Manager training & Indicator variable for whether the surveyed manager participated in training courses during the survey year. \\
\hline Manager training on ICT & $\begin{array}{l}\text { Indicator variable for whether the surveyed manager participated in training courses about information technology during the } \\
\text { survey year. }\end{array}$ \\
\hline Outsourcing & Indicator variable for whether the firm outsourced any activity during the survey year. \\
\hline Complex software use indicator & $\begin{array}{l}\text { Indicator variable for whether the firm uses client management, production or administration and business software packages. } \\
\text { The indicator variable is equal to } 0 \text { when the firm does not use any of these types of software or does not have a computer. }\end{array}$ \\
\hline Computer use indicator & Indicator variable for whether the firm has at least one computer. \\
\hline \multicolumn{2}{|l|}{$\begin{array}{l}\text { Average number of computers per } \\
\text { firm }\end{array}$} \\
\hline Firm size & $\begin{array}{l}\text { Firm size is captured by the firms' total number of employees. Micro firms are those with } 5 \text { employees or less, small firms are } \\
\text { those with } 6 \text { to } 20 \text { employees; medium firms are those with } 20 \text { to } 50 \text { employees and large firms are those with } 51 \text { employees or } \\
\text { more. }\end{array}$ \\
\hline Firm age & Years since the firm began its activities. \\
\hline Exporter & Indicator variable for whether the firm exported goods or services during the survey year. \\
\hline Foreign-owned & Indicator variable for whether the firm has owners that are not Chilean. \\
\hline Credit constrained & $\begin{array}{l}\text { Indicator variable for whether firm was rejected when asking for credit or did not accept credit conditions. The indicator is equal to } \\
0 \text { if the firm obtained a credit or did not ask for credit. }\end{array}$ \\
\hline Manager age & Age of the firm main manager. \\
\hline Manager years of experience & Number of years of work experience of firm main manager \\
\hline Manager with second. education & Indicator variable for whether the firm main manager has secondary education, complete or incomplete. \\
\hline Manager with college education & Indicator variable for whether the firm main manager has college (or higher) education, complete or incomplete. \\
\hline
\end{tabular}

${ }^{1}$ The sample period encompasses the 2007-2008 global financial crisis, when gross domestic product fell and labor market outcomes worsened in Chile. However, the crisis impacts were short-lived (Cruces, Fields, Jaume, \& Viollaz, 2017; SEDLAC, 2017).

${ }^{2}$ For exogeneity reasons pre-sample period ICT intensity in 2003 is used.

${ }^{3}$ Three recent studies use ELE (2007 and 2009 rounds) to analyze links between ICT and innovation (Santoleri, 2015; Alvarez, 2016) and innovation and wages (Cirillo, 2016).

${ }^{4}$ Some authors argue the increased automation and streamlining of processes accompanying the use of business and production software might even constrain workers in their creativity (Engelstätter \& Sarbu, 2013).

${ }^{5}$ For more details see http://www.oecd.org/skills/piaac/.

${ }^{6}$ For example, a large manufacturing firm located in the Metropolitan region reports having managers, administrative workers, professionals and technical workers and no unskilled production and services workers in 2007 but having only unskilled production and services workers in 2013. 
${ }^{7}$ While it would be valuable to compare the complex software adoption impacts on firm labor-related variables to those of more traditional ICT adoption we do not pursue that exercise because our sample exhibits insufficient variation in firm computer use over time to be able to estimate such impacts.

${ }^{8}$ From the 25 per cent of firms switching complex software adoption status, 12 per cent start using the software, while 13 per cent stop using the software. In Table I of the online Supplementary Materials we show that $84 \%$ of switchers are micro and small firms and 30\% are firms operating in wholesale and retail trade, $16 \%$ in manufacturing, and $12 \%$ in real estate and business activities sectors.

${ }^{9}$ A similar type of instrument was used by Iacovone, Pereira-Lopez and Schiffbauer (2016) studying the impact on productivity of the use of computers by firms in Mexico. The 2003 Chilean input-output table is pre-determined from the point of view of firms' ICT adoption and employment decisions in 2007 and 2013.

${ }^{10}$ The corresponding OLS estimates are provided in Table V in the online Supplementary Materials.

${ }^{11}$ Each specification includes the logarithm of the level of employment of an occupation to which we add 1 so as to keep in the estimating sample observations from firms with no employment in that occupation.

${ }^{12}$ Our conclusion of output and employment expansion due to complex software adoption draws on the positive and significant impacts on two occupation types combined with the insignificant impact on the other two occupation types. In unreported regressions we estimate the direct impact of complex software adoption on firm gross income from main activity and firm total employment and find those to be positive (though statistically insignificant at conventional confidence levels).

${ }^{13}$ The first-stage equation (not reported) includes a similar specification. 


\section{SUPPLEMENTARY MATERIALS Software Adoption and the Skill Content of Occupations in Chilean Firms}

\section{Section 1. Data}

\subsection{ELE Survey}

The Encuesta Longitudinal de Empresas (ELE) was developed by the Sub-secretariat of Economy in the Ministry of Economy, Promotion, and Tourism and the University of Chile (Center of Microdata from the Economics Department) and implemented by the National Statistical Institute. ELE is representative of all economic activities in Chile captured by the International Standard Industry Classification (ISIC) Revision 3 except for public administration, health, education, domestic service, and extraterritorial organizations. The sampling frame from which firms are selected to be surveyed, with a stratification by sector and firm size, is the Directory from INE and a registry from the Chilean internal revenue service. In this study, we use the 2007 and 2013 rounds of the survey. In each round of the survey, a panel design establishes to select as many firms as possible from the immediately preceding round. If a threshold of 50 per cent of the cross-section size by sector and firm size cannot be reached with firms included in the immediately previous survey, the missing firms are replaced by firms that were present in the survey round prior to that. Our main firm-level sample is a balanced panel of 1,852 firms observed both in 2007 and in 2013.

\subsubsection{Analysis of Switching Firms}

Table I. Firms Switching Complex Software Use Status, 2007- 2013

\begin{tabular}{|c|c|c|}
\hline & $\begin{array}{c}\text { Share of firms } \\
\text { using complex } \\
\text { software in } 2007\end{array}$ & $\begin{array}{c}\text { Share of firms } \\
\text { switching software } \\
\text { use status } \\
\text { between } 2007 \text { and } \\
2013 \\
\end{array}$ \\
\hline Overall panel sample & $46.7 \%$ & $25.4 \%$ \\
\hline \multicolumn{3}{|l|}{ By firm size } \\
\hline Micro & $16.9 \%$ & $40.6 \%$ \\
\hline Small & $44.8 \%$ & $43.3 \%$ \\
\hline Medium & $66.6 \%$ & $9.2 \%$ \\
\hline Large & $86.4 \%$ & $6.9 \%$ \\
\hline \multicolumn{3}{|l|}{ Bysector } \\
\hline Agriculture, hunting, fishing and forestry & $27.3 \%$ & $8.5 \%$ \\
\hline Mining and quarrying & $40.4 \%$ & $0.7 \%$ \\
\hline Manufacturing & $45.4 \%$ & $15.8 \%$ \\
\hline Electricity, gas and water supply & $95.3 \%$ & $0.1 \%$ \\
\hline Construction & $39.4 \%$ & $12.9 \%$ \\
\hline Wholesale and retail trade & $33.6 \%$ & $30.0 \%$ \\
\hline Hotels and restaurants & $18.3 \%$ & $4.8 \%$ \\
\hline Transport, storage and communications & $36.1 \%$ & $7.7 \%$ \\
\hline Financial intermediation & $88.3 \%$ & $0.1 \%$ \\
\hline Real estate and business activities & $57.2 \%$ & $12.4 \%$ \\
\hline Other service activities & $61.1 \%$ & $7.1 \%$ \\
\hline
\end{tabular}

Source: Authors' calculations based on ELE's 2007 and 2013 waves. 


\subsubsection{Analysis of correlates of firm use of complex software}

We investigate the profile of complex software adoption across firms in the sample. Table II reports the estimated coefficients from reduced-form Probit regressions documenting interesting patterns. Larger firms, older firms, exporting and foreign-owned firms, firms not experiencing credit constraints are all more likely to use advanced technology, even after controlling for sector of activity and region. The quality of the managerial human capital is a critical determinant of technological use: firms with younger managers and/or with higher levels of formal education and past labor market experience are more likely to use complex software.

Table II. Correlates of Firm Use of Complex Software

\begin{tabular}{|c|c|c|c|c|c|c|c|c|c|}
\hline & \multicolumn{9}{|c|}{ Dependent variable: Firm use of complex software (probit estimation) } \\
\hline & (1) & (2) & (3) & (4) & (5) & (6) & (7) & (8) & (9) \\
\hline \multirow[t]{2}{*}{ Small } & 0.815 & & & & & & & & 0.825 \\
\hline & {$[0.0109]^{\star \star \star *}$} & & & & & & & & {$[0.0114]^{\star \star \star}$} \\
\hline \multirow[t]{2}{*}{ Medium } & 1.254 & & & & & & & & 1.156 \\
\hline & {$[0.0153]^{\star \star \star}$} & & & & & & & & {$[0.0158]^{\star \star \star}$} \\
\hline \multirow[t]{2}{*}{ Large } & 2.040 & & & & & & & & 1.881 \\
\hline & {$[0.0195]^{\star \star \star}$} & & & & & & & & {$[0.0206]^{* * *}$} \\
\hline \multirow[t]{2}{*}{ Firm age (log) } & & 0.150 & & & & & & & 0.0876 \\
\hline & & {$[0.00708]^{\star \star *}$} & & & & & & & {$[0.00824]^{\star \star \star}$} \\
\hline \multirow[t]{2}{*}{ Exporter } & & & 0.767 & & & & & & 0.0658 \\
\hline & & & {$[0.0218]^{\star \star *}$} & & & & & & {$[0.0246]^{* * *}$} \\
\hline \multirow[t]{2}{*}{ Foreign-owned } & & & & 1.799 & & & & & 1.256 \\
\hline & & & & {$[0.0800]^{\star \star *}$} & & & & & {$[0.0970]^{\star \star \star}$} \\
\hline \multirow[t]{2}{*}{ Credit constrained } & & & & & -0.278 & & & & -0.151 \\
\hline & & & & & {$[0.0249]^{\star \star \star}$} & & & & {$[0.0264]^{\star \star \star}$} \\
\hline \multirow{2}{*}{ Manager less than 50 years old } & & & & & & 0.214 & & & 0.180 \\
\hline & & & & & & {$[0.00983]^{\star \star \star}$} & & & {$[0.0116]^{\star \star *}$} \\
\hline \multirow[t]{2}{*}{ Manager with more than 10 years of experience } & & & & & & & 0.0437 & & 0.215 \\
\hline & & & & & & & {$[0.0115]^{\star \star \star}$} & & {$[0.0135]^{\star \star \star}$} \\
\hline \multirow[t]{2}{*}{ Manager with secondary education } & & & & & & & & 0.768 & 0.592 \\
\hline & & & & & & & & {$[0.0295]^{\star \star \star}$} & {$[0.0311]^{* \star *}$} \\
\hline Manager with college education & & & & & & & & $\begin{array}{c}1.296 \\
{[0.0290]^{\star \star \star}}\end{array}$ & $\begin{array}{c}0.970 \\
{[0.0305]^{\star \star \star}}\end{array}$ \\
\hline \multirow[t]{2}{*}{ Mining and quarrying } & 0.434 & 0.4 & 0.373 & 0.347 & 0.382 & 0.318 & 0.38 & 0.345 & 0.444 \\
\hline & {$[0.0526]^{\star \star \star}$} & {$[0.0468]^{\star \star \star}$} & {$[0.0466]^{\star \star \star}$} & {$[0.0468]^{\star \star \star}$} & {$[0.0465]^{\star \star \star}$} & {$[0.0466]^{\star \star \star}$} & {$[0.0467]^{\star \star \star}$} & {$[0.0472]^{\star \star \star}$} & {$[0.0540]^{\star \star \star}$} \\
\hline \multirow[t]{2}{*}{ Manufacturing } & 0.0643 & 0.013 & -0.00677 & 0.0144 & 0.0202 & -0.016 & 0.00932 & 0.0164 & 0.0753 \\
\hline & {$[0.0191]^{\star \star *}$} & {$[0.0174]$} & {$[0.0175]$} & {$[0.0175]$} & {$[0.0175]$} & {$[0.0174]$} & {$[0.0174]$} & {$[0.0181]$} & {$[0.0197]^{\star \star *}$} \\
\hline \multirow[t]{2}{*}{ Electricity, gas and water supply } & 1.885 & 2.077 & 2.113 & 2.076 & 2.065 & 2.01 & 2.084 & 1.805 & 1.657 \\
\hline & {$[0.169]^{\star \star \star}$} & {$[0.141]^{\star \star \star}$} & {$[0.140]^{\star * \star}$} & {$[0.141]^{\star \star \star}$} & {$[0.141]^{\star \star \star \star}$} & {$[0.142]^{\star \star \star}$} & {$[0.141]^{\star \star \star}$} & {$[0.139]^{\star \star *}$} & {$[0.162]^{\star \star \star}$} \\
\hline \multirow[t]{2}{*}{ Construction } & -0.0539 & 0.173 & 0.182 & 0.139 & 0.138 & 0.11 & 0.132 & 0.0575 & -0.0437 \\
\hline & {$[0.0207]^{\star \star *}$} & {$[0.0192]^{\star \star *}$} & {$[0.0192]^{* * *}$} & {$[0.0190]^{* * *}$} & {$[0.0191]^{\star \star *}$} & {$[0.0190]^{\star \star *}$} & {$[0.0190]^{\star \star \star}$} & {$[0.0192]^{\star \star \star}$} & {$[0.0210]^{\star \star}$} \\
\hline \multirow[t]{2}{*}{ Wholesale and retail trade } & 0.429 & 0.109 & 0.0995 & 0.0795 & 0.0844 & 0.0555 & 0.0868 & 0.0913 & 0.403 \\
\hline & {$[0.0176]^{\star \star \star}$} & {$[0.0160]^{\star \star \star}$} & {$[0.0161]^{\star \star *}$} & {$[0.0160]^{\star \star \star}$} & {$[0.0160]^{\star \star \star}$} & {$[0.0160]^{\star \star \star}$} & {$[0.0160]^{\star \star \star}$} & {$[0.0169]^{\star \star \star}$} & {$[0.0185]^{\star \star \star}$} \\
\hline \multirow[t]{2}{*}{ Hotels and restaurants } & -0.370 & -0.283 & -0.343 & -0.311 & -0.307 & -0.356 & -0.31 & -0.268 & -0.331 \\
\hline & {$[0.0251]^{\star * *}$} & {$[0.0236]^{\star \star *}$} & {$[0.0238]^{\star \star \star}$} & {$[0.0236]^{\star \star \star}$} & {$[0.0236]^{\star \star *}$} & {$[0.0236]^{\star \star *}$} & {$[0.0236]^{\star \star *}$} & {$[0.0243]^{\star \star *}$} & {$[0.0258]^{\star * *}$} \\
\hline \multirow[t]{2}{*}{ Transport, storage and communications } & 0.357 & 0.31 & 0.312 & 0.267 & 0.28 & 0.212 & 0.277 & 0.241 & 0.322 \\
\hline & {$[0.0226]^{\star \star * *}$} & {$[0.0207]^{\star \star \star \star}$} & {$[0.0207]^{\star \star \star}$} & {$[0.0207]^{\star \star \star}$} & {$[0.0206]^{\star \star \star}$} & {$[0.0208]^{\star \star \star}$} & {$[0.0207]^{\star \star \star}$} & {$[0.0207]^{\star \star \star}$} & {$[0.0229]^{\star \star \star}$} \\
\hline \multirow[t]{2}{*}{ Financial intermediation } & 0.955 & 1.182 & 1.183 & 1.067 & 1.168 & 1.101 & 1.162 & 0.962 & 0.752 \\
\hline & {$[0.0825]^{\star \star \star}$} & {$[0.0659]^{\star \star \star}$} & {$[0.0665]^{\star \star \star}$} & {$[0.0709]^{\star \star \star}$} & {$[0.0655]^{\star \star \star}$} & {$[0.0658]^{\star \star *}$} & {$[0.0656]^{\star \star \star}$} & {$[0.0659]^{\star \star \star}$} & {$[0.0875]^{\star \star \star}$} \\
\hline \multirow[t]{2}{*}{ Real estate and business activities } & 0.455 & 0.336 & 0.303 & 0.266 & 0.275 & 0.178 & 0.268 & 0.137 & 0.504 \\
\hline & {$[0.0193]^{\star \star \star}$} & {$[0.0178]^{\star \star \star}$} & {$[0.0174]^{\star \star \star}$} & {$[0.0174]^{\star \star \star}$} & {$[0.0174]^{\star \star \star}$} & {$[0.0178]^{\star \star \star}$} & {$[0.0175]^{\star \star \star}$} & {$[0.0179]^{\star \star \star}$} & {$[0.0208]^{\star \star \star *}$} \\
\hline Other service activities & 0.609 & 0.453 & 0.48 & 0.416 & 0.432 & 0.412 & 0.439 & 0.283 & 0.474 \\
\hline & {$[0.0246]^{* \star *}$} & {$[0.0222]^{\star \star *}$} & {$[0.0222]^{\star \star \star}$} & {$[0.0223]^{\star \star \star}$} & {$[0.0222]^{\star \star \star}$} & {$[0.0222]^{\star \star *}$} & {$[0.0222]^{\star \star \star}$} & {$[0.0226]^{\star \star \star}$} & {$[0.0247]^{\star \star \star}$} \\
\hline Year Fixed Effects & Yes & Yes & Yes & Yes & Yes & Yes & Yes & Yes & Yes \\
\hline Region Fixed Effects & Yes & Yes & Yes & Yes & Yes & Yes & Yes & Yes & Yes \\
\hline Observations & 3,704 & 3,704 & 3,704 & 3,704 & 3,704 & 3,704 & 3,704 & 3,704 & 3,704 \\
\hline R-squared & 0.218 & 0.077 & 0.079 & 0.078 & 0.070 & 0.073 & 0.069 & 0.108 & 0.249 \\
\hline
\end{tabular}

Source: Authors' calculations based on ELE's 2007 and 2013 waves and 2014 Chile PIAAC survey.

Notes: Robust standard errors in brackets. ${ }^{* *},{ }^{* *}$, and * indicate significance at 1,5 , and 10 per cent confidence levels, respectively. All variables are defined in Appendix Table 1. The indicator variable for manager less than 50 years old is based on manager age and the indicator variable for manager with more than 10 years of experience is based on the number of years of experience of the manager. The omitted size category are micro firms, the omitted manager education category is primary education, and the omitted sector is agriculture, hunting, fishing and forestry. 


\subsection{PIAAC Survey and Definition of Task Measures}

We define the task content of occupations for three types of tasks, abstract, routine and manual tasks as in Autor and Handel (2013). We identify in the PIAAC survey the questions that are very similar to those used by other studies relying on the DOT, PDII, O*NET or STEP surveys. Abstract comprises abstract problem-solving and creative, organizational, interactive and managerial tasks which are associated with the following variables in the PIAAC survey: the frequency of reading material and of writing material at work; the frequency of math tasks involving at least high-school mathematics; the frequency of problem-solving tasks requiring at least 30 minutes to be solved; the frequency of interaction with other people at work; the frequency of learning at work; the frequency of making presentations or giving speeches, and an indicator for the supervision of other workers. ${ }^{i}$ Routine involves codifiable tasks that follow explicit procedures and is associated with the following variables in the PIAAC survey: rigidities in the adjustment of the sequence of tasks at work; the rigidities in the adjustment of working hours at work; and the rigidities in the adjustment of the speed or rate of work. ${ }^{\text {ii }}$ These variables capture the degree of autonomy a worker has in performing his job. Finally, Manual comprises tasks that require physical adaptability and manual dexterity and are associated with the following variables in the PIAAC survey: the frequency of working physically for a long period and the frequency of using accuracy with hands or fingers. ${ }^{\text {iii }}$

To construct the task content of occupations using the PIAAC survey we focus on 1,624 adult workers that are wage employees in the private sector employed in any of the sectors covered by ELE. We match the 262 detailed occupations in our PIAAC sample (classified at the 4-digit level of the International Standard Classification of Occupations (ISCO) 2008) to the four broad occupations in ELE: managers, administrative workers, professionals and technical workers and unskilled production and services workers. ${ }^{\text {iv }}$ Finally, we combine the variables associated with each type of task in the PIAAC survey (shown in Table III below) into a single task content measure for each occupation in the ELE survey following the approach of Acemoglu and Autor (2011). We proceed in three steps:

1) For each variable associated with any of the three tasks we calculate the mean and standard deviation across the sample of 1,624 workers so as to be able to standardize the variable by subtracting the mean and dividing by the standard deviation.

2) For each worker we obtain scores for each of the three types of tasks by adding all the standardized variables obtained in 1) associated with abstract tasks (8 variables), associated with routine ( 3 variables), and associated with manual tasks ( 2 variables). For all final task scores to have a zero mean and standard deviation of one, we do one additional standardization of the three task scores by subtracting their mean and dividing by their standard deviation.

3) For each of the four occupations in ELE, we calculate a weighted average of the value of each of the three final standardized task scores obtained in 2) using as weights the contribution of each detailed occupation mapped to that broad occupation to total hours of work in the previous week, as reported in the PIAAC survey. ${ }^{\mathrm{V}}$ Since the resulting task content measures cannot be compared across occupations, we standardize them using the mean and standard deviation taken 
across the four occupations in ELE. These normalized task content measures are an input for the firm-level task indexes.

The advantage of this methodology is that the scale of the abstract, routine, and manual task content measures is comparable across tasks and across occupations in ELE. Table 1 in the main text provides for each occupation in ELE the average of each task content measure. Higher values of the task content measure indicate that that type of tasks is more important for that occupation. For managers, the most important tasks are abstract, followed by manual tasks, while routine tasks are the least important. This ranking is very intuitive as managers are expected to perform the problem-solving tasks included in the definition of abstract tasks. The relative importance of manual tasks for managers is in line with Messina et al. (2016) who find for Latin American countries other than Chile that occupations with a high content of manual tasks include high-level occupations like database and network professionals, managing directors and chief executives. As expected, routine tasks are of lesser relevance for managers, who typically have more freedom to decide the way they work. For administrative workers, the most important tasks are routine, which again is a finding in line with expectations. For professionals and technical workers, the most important tasks are abstract, followed by routine tasks - these are the set of tasks we expect to be replaced by the complex software. Finally, for unskilled production and services workers the most important tasks are manual followed by routine.

Table III. Variables Associated with Four Types of Tasks in the PIAAC Survey

\begin{tabular}{ll}
\hline Tasks measures & \multicolumn{1}{c}{ Variables } \\
\hline Abstract & (1) Frequency of reading material (1 to 5) \\
& (2) Frequency of writing material (1 to 5) \\
& (3) Frequency of math tasks involving at least high school mathematics (1 to 5) \\
& (4) Frequency of problem solving tasks requiring at least 30 min to be solved (1 to 5) \\
& (5) Frequency of interaction with other people (1 to 5) \\
& (6) Frequncy of learning at work (1 to 5) \\
& (7) Frequency of making presentations or giving speeches (1 to 5) \\
& (8) Supervising other employees (Yes/No) \\
\hline Routine & (1) Rigidities in adjustment of sequence of tasks (1 to 5) \\
& (2) Rigidities in adjus tment of working hours (1 to 5) \\
(3) Rigidities in adjustment of speed or rate of work (1 to 5)
\end{tabular}

Source: 2014 Chile PIAAC Survey.

Notes: Variables measuring the frequency of a particular activity are expressed on a scale ranging from 1 (indicating very low frequency) to 5 (indicating very high frequency). Variables measuring the rigidity of a particular activity are expressed on a scale ranging from 1 (indicating little rigidity) to 5 (indicating strong rigidity). 


\subsection{CASEN Survey}

Table IV. Summary Statistics on Regional Variables from CASEN

\begin{tabular}{lcccc}
\hline & \multicolumn{2}{c}{ Computer } & \multicolumn{2}{c}{ Cell Phone } \\
\cline { 2 - 5 } & 2006 & 2013 & 2006 & 2013 \\
& $(1)$ & $(2)$ & $(5)$ & $(6)$ \\
\hline Tarapacá & 35.10 & 61.62 & 63.80 & 90.94 \\
Antofagasta & 43.56 & 72.23 & 68.42 & 93.86 \\
Atacama & 36.72 & 58.16 & 64.75 & 92.88 \\
Coquimbo & 26.37 & 54.25 & 59.12 & 92.16 \\
Valparaíso & 32.91 & 59.45 & 61.78 & 89.85 \\
O'Higgins & 24.81 & 51.26 & 59.40 & 89.84 \\
Del Maule & 20.74 & 43.24 & 58.82 & 90.36 \\
BioBío & 28.33 & 55.54 & 56.53 & 88.77 \\
Araucanía & 23.83 & 43.28 & 56.34 & 89.16 \\
Los Lagos & 23.74 & 51.13 & 63.82 & 89.37 \\
Aysén & 26.27 & 59.05 & 62.68 & 92.53 \\
Magallanes y Antártica & 46.75 & 68.48 & 57.69 & 89.36 \\
Región Metropolitana & 43.47 & 63.99 & 62.86 & 89.21 \\
Los Ríos & 23.79 & 47.79 & 53.22 & 88.75 \\
Arica y Parinacota & 32.40 & 59.56 & 52.61 & 87.48 \\
\hline Country Avg. & 31.25 & 56.60 & 60.12 & 90.30 \\
\hline \hline
\end{tabular}

Source: CASEN's 2006 and 2013 waves.

\section{Section 2. Additional Results}

\subsection{OLS Estimates}

Table V. OLS Impact of Complex Software Use on Firm Occupation Shares and Task Indexes

\begin{tabular}{|c|c|c|c|c|}
\hline \multirow[t]{2}{*}{ Dependent variable: } & \multicolumn{4}{|c|}{ Panel A. Firm employment shares } \\
\hline & Managers & $\begin{array}{c}\text { Professionals } \\
\& \text { technical } \\
\text { workers }\end{array}$ & $\begin{array}{c}\text { Administ. } \\
\text { workers }\end{array}$ & $\begin{array}{l}\text { Unskilled } \\
\text { production \& } \\
\text { services } \\
\text { workers }\end{array}$ \\
\hline \multirow[t]{2}{*}{ Firm complex software use } & 0.0176 & 0.0212 & -0.00171 & -0.0372 \\
\hline & {$[0.0156]$} & {$[0.0300]$} & {$[0.0276]$} & {$[0.0343]$} \\
\hline \multirow[t]{3}{*}{ Dependent variable: } & \multicolumn{4}{|c|}{ Panel B. Firm task indexes } \\
\hline & Abstract & Routine & Manual & \\
\hline & (1) & (2) & (3) & \\
\hline Firm complex software use & $\begin{array}{c}0.0642 \\
{[0.0526]}\end{array}$ & $\begin{array}{c}-0.0466 \\
{[0.0410]}\end{array}$ & $\begin{array}{c}-0.0591 \\
{[0.0499]}\end{array}$ & \\
\hline Observations & 3,704 & 3,704 & 3,704 & \\
\hline
\end{tabular}

Source: Authors' calculations based on ELE's 2007 and 2013 waves and 2014 Chile PIAAC survey.

Notes: Robust standard errors in brackets. ***, **, and * indicate significance at 1,5 , and 10 per cent confidence levels, respectively. All regressions control for firm and year fixed effects and include time-varying firm characteristics (firm size categories, firm age (in logs), exporter, foreignowned, and credit constrained indicators, age of the main manager (in logs), number of years of experience of the main manager (in logs) and indicators for the degree of education of the main manager), time-varying region characteristics (average per capita household income in the region (in logs), share of urban population, average number of years of education of population in the region (in logs)), number of computers used by firms in the region-sector, as well as region-specific time trends. 


\subsection{Robustness Checks}

We test the robustness of the main findings in the paper to different concerns. First, we consider an alternative methodology to compute the firm-level task indexes, following Autor and Handel (2013). We are interested in assessing whether changing the methodology used to define the task measures results in different task content of occupations and different impacts of the adoption of complex software. The average of each task measure for each occupation using Autor and Handel (2013) methodology is presented in Table VI below. Second, we use an alternative measure of the regional adoption of new technologies in the first-stage of the IV estimation. Our objective is to test whether regional household computer use is capturing the regional adoption of new technologies or is capturing other regional trends. The alternative measure is the share of households in the region with at least one cell phone. ${ }^{\text {vi }}$ Third, we explore an alternative to the use of ELE's cross-sectional sampling weights (exploited in our main results) consisting in using no sampling weights. Fourth, we test the robustness of our results to the inclusion of the group of 140 firms exhibiting very large changes in employment composition between 2007 and 2013 (which are excluded from the estimating sample used in the main analysis). Fifth, we explore whether our results are driven by the fact that only a small share of firms in our sample $(25 \%)$ change their status in the adoption of complex software over time. We re-estimate our main models ignoring the panel structure of the data, including region and sector fixed effects instead of firm fixed effects. Sixth, we explore the possibility that our main results are driven by sector-specific trends related for instance to the commodity boom experienced by Chile over the same period. Finally, we expand the measurement of task content of occupations to allow variation also across sectors. ${ }^{\text {vi }}$ Table VII reports the average of each task measure for each occupation in each aggregate sector.

Table VI. Task Content Measures based on the PIAAC Survey by Occupation in ELE Following Methodology of Autor and Handel (2013)

\begin{tabular}{lccc}
\hline & Abstract & Routine & Manual \\
\hline Managers & 0.883 & -0.940 & -0.501 \\
Administrative workers & -0.052 & 0.121 & -0.044 \\
Professionals and technical workers & 0.358 & -0.473 & -0.481 \\
Unskilled production and services workers & -0.154 & 0.185 & 0.203 \\
\hline
\end{tabular}

Source: Authors' calculations based on ELE's 2007 and 2013 waves and 2014 Chile PIAAC survey. 
Table VII. Task Content Measures based on the PIAAC Survey by Occupation and Sector of Activity in ELE Following Methodology of Autor and Acemoglu (2011)

\begin{tabular}{lccc}
\hline & Abstract & Routine & Manual \\
\hline Managers & $\mathbf{1 . 0 8 1}$ & $\mathbf{- 1 . 3 2 0}$ & $\mathbf{- 1 . 1 3 7}$ \\
Primary sector & 0.935 & -1.239 & 0.337 \\
Manufacturing & 1.174 & -1.218 & -0.912 \\
Services & 1.073 & -1.346 & -1.251 \\
\hline Administrative workers & $\mathbf{- 0 . 1 2 7}$ & $\mathbf{0 . 5 5 6}$ & $\mathbf{0 . 2 7 4}$ \\
Primary sector & -0.215 & 0.136 & -0.306 \\
Manufacturing & -0.331 & 0.672 & 0.415 \\
Services & -0.091 & 0.621 & 0.295 \\
\hline Professionals and technical workers & $\mathbf{0 . 3 4 7}$ & $\mathbf{- 0 . 1 9 1}$ & $\mathbf{- 0 . 3 6 2}$ \\
Primary sector & 0.593 & -0.096 & -1.197 \\
Manufacturing & 0.340 & -0.404 & -0.718 \\
Services & 0.333 & -0.156 & -0.189 \\
\hline Unskilled production and services workers & $\mathbf{- 1 . 3 0 2}$ & $\mathbf{0 . 9 5 5}$ & $\mathbf{1 . 2 2 5}$ \\
Primary sector & -1.314 & 1.199 & 1.166 \\
Manufacturing & -1.182 & 0.950 & 1.216 \\
Services & -1.315 & 0.882 & 1.145 \\
\hline
\end{tabular}

Source: Authors' calculations based on ELE's 2007 and 2013 waves and 2014 Chile PIAAC survey.

Panels A to G in Table VIII report results from all these robustness checks. ${ }^{\text {viii }}$ For brevity we report only the impacts on firm-level task indexes in Table VII but we also include in the discussion of results below those for the impacts on firm-level occupation shares. ${ }^{\text {ix }}$ Most estimations show a decrease in the abstract task index along with increases in the routine and the manual indexes. ${ }^{\mathrm{x}}$ The main findings reported in the paper's Section 5 are robust to changes in sample size, instrumental variable definition, measurement of task indexes, weighting scheme, and inclusion of sector-specific time trends as control variables. The estimated reduction in the abstract task index and increases in routine and manual indexes reflect adjustments in the occupational composition, where the professionals and technical category --intensive in abstract and routine tasks performed by the complex software-- loses share and the unskilled production and services category gains share in firm total employment.

One additional threat to our identification strategy is that the growing demand for computers by households in a region could directly impact the output and employment of firms involved in the production or sale of computers. To address this threat, we exclude from our sample two sectors -- IT producers (manufacturing) and IT sellers (wholesale and retail trade). ${ }^{\mathrm{xi}}$ The results, reported in Panels $\mathrm{H}$ and $\mathrm{I}$ of Table VIII, indicate that our main findings remain robust. 
Table VIII. Robustness Tests - Impact of Firm Complex Software Use on Task Indexes

\begin{tabular}{|c|c|c|c|}
\hline \multirow[b]{2}{*}{ Dependent variable: } & \multicolumn{3}{|c|}{ Second-stage - Firm Task indexes } \\
\hline & $\begin{array}{l}\text { Abstract } \\
\text { (1) }\end{array}$ & $\begin{array}{l}\text { Routine } \\
\text { (2) }\end{array}$ & $\begin{array}{l}\text { Manual } \\
\text { (3) }\end{array}$ \\
\hline & \multicolumn{3}{|c|}{ Panel A: Autor \& Handel (2013) method } \\
\hline Firm complex software use & $\begin{array}{c}-0.550 \\
{[0.219]^{\star \star}}\end{array}$ & $\begin{array}{c}0.669 \\
{[0.246]^{\star \star *}}\end{array}$ & $\begin{array}{c}0.519 \\
{[0.173]^{\star \star \star}}\end{array}$ \\
\hline \multirow{2}{*}{ Observations } & 3,704 & 3,704 & 3,704 \\
\hline & \multicolumn{3}{|c|}{ Panel B: IV based on share of households with cell phone } \\
\hline Firm complex software use & $\begin{array}{c}-1.286 \\
{[0.535]^{\star *}}\end{array}$ & $\begin{array}{c}1.203 \\
{[0.508]^{\star *}}\end{array}$ & $\begin{array}{c}1.313 \\
{[0.530]^{\star *}}\end{array}$ \\
\hline \multirow[t]{2}{*}{ Observations } & 3,704 & 3,704 & 3,704 \\
\hline & \multicolumn{3}{|c|}{ Panel C: Without weights } \\
\hline Firm complex software use & $\begin{array}{c}-4.481 \\
{[2.668]^{*}}\end{array}$ & $\begin{array}{c}4.010 \\
{[2.434]^{*}}\end{array}$ & $\begin{array}{c}4.399 \\
{[2.599]^{*}}\end{array}$ \\
\hline \multirow[t]{2}{*}{ Observations } & 3,704 & 3,704 & 3,704 \\
\hline & \multicolumn{3}{|c|}{ Panel D: Complete sample } \\
\hline Firm complex software use & $\begin{array}{c}-2.680 \\
{[1.476]^{\star}}\end{array}$ & $\begin{array}{c}2.030 \\
{[1.119]^{\star}}\end{array}$ & $\begin{array}{c}2.722 \\
{[1.424]^{\star}}\end{array}$ \\
\hline \multirow[t]{2}{*}{ Observations } & 3,984 & 3,984 & 3,984 \\
\hline & \multicolumn{3}{|c|}{ Panel E: Ignoring panel structure of the data } \\
\hline Firm complex software use & $\begin{array}{l}-0.749 \\
{[0.495]}\end{array}$ & $\begin{array}{c}0.665 \\
{[0.368]^{*}}\end{array}$ & $\begin{array}{c}0.784 \\
{[0.466]^{*}}\end{array}$ \\
\hline \multirow[t]{2}{*}{ Observations } & 3,704 & 3,704 & 3,704 \\
\hline & \multicolumn{3}{|c|}{ Panel F: Including sector-specific time trends } \\
\hline Firm complex software use & $\begin{array}{c}-1.327 \\
{[0.574]^{\star *}}\end{array}$ & $\begin{array}{c}1.222 \\
{[0.541]^{\star *}}\end{array}$ & $\begin{array}{c}1.349 \\
{[0.571]^{\star *}}\end{array}$ \\
\hline \multirow[t]{2}{*}{ Observations } & 3,704 & 3,704 & 3,704 \\
\hline & \multicolumn{3}{|c|}{ Panel G: Task measures by occupation and sector } \\
\hline Firm complex software use & $\begin{array}{c}-1.248 \\
{[0.507]^{\star *}}\end{array}$ & $\begin{array}{c}1.089 \\
{[0.447]^{* *}}\end{array}$ & $\begin{array}{c}1.238 \\
{[0.523]^{\star *}}\end{array}$ \\
\hline \multirow[t]{2}{*}{ Observations } & 3,704 & 3,704 & 3,704 \\
\hline & \multicolumn{3}{|c|}{ Panel $\mathrm{H}$ : Excluding manufacturing sector } \\
\hline \multirow[t]{2}{*}{ Firm complex software use } & -0.963 & 0.890 & 0.991 \\
\hline & {$[0.437]^{* *}$} & {$[0.396]^{* *}$} & {$[0.426]^{* *}$} \\
\hline \multirow[t]{2}{*}{ Observations } & 3,124 & 3,124 & 3,124 \\
\hline & \multicolumn{3}{|c|}{ Panel I: Excluding wholesale and retail trade sector } \\
\hline Firm complex software use & $\begin{array}{c}-1.681 \\
{[0.808]^{* *}}\end{array}$ & $\begin{array}{c}1.511 \\
{[0.778]^{\star}}\end{array}$ & $\begin{array}{c}1.695 \\
{[0.813]^{* *}}\end{array}$ \\
\hline Observations & 3,178 & 3,178 & 3,178 \\
\hline
\end{tabular}

Source: Authors' calculations based on ELE's 2007 and 2013 waves and 2014 Chile PIAAC survey.

Notes: Robust standard errors in brackets clustered by region-sector. ${ }^{* *}, * *$, and * indicate significance at 1,5 , and 10 per cent confidence levels, respectively. All regressions control for firm and year fixed effects and include time-varying firm characteristics (size categories, age (in logs), exporter, foreign-owned, and credit constrained indicators, age of the main manager (in logs), number of years of experience of the main manager (in logs) and indicators for the degree of education of the main manager), time-varying region characteristics (average per capita household income (in logs), share of urban households, and average number of years of education of households (in logs)), number of computers used by firms in the region-sector, as well as region-specific time trends.

We also test whether our main results are led by regions or economic sectors with a high share of complex software use in 2007 and 2013. We proceed by re-estimating our main specifications eliminating from the sample the sectors or regions that may appear as outliers in Figure 1 in the main test. The results presented in Tables IX and X are unchanged. 
Table IX. Firm Complex Software Use, Employment Composition and Task Indexes Excluding "Outlier" Sectors Utilities and Financial Intermediation

\begin{tabular}{lcccc}
\hline Dependent variable: & \multicolumn{4}{c}{ Panel B: Second-stage - Firm employment shares } \\
\cline { 2 - 5 } & Managers & $\begin{array}{c}\text { Professionals \& } \\
\text { technical } \\
\text { workers }\end{array}$ & $\begin{array}{c}\text { Administ. } \\
\text { workers }\end{array}$ & $\begin{array}{c}\text { Unskilled } \\
\text { production \& } \\
\text { services } \\
\text { workers } \\
(4)\end{array}$ \\
\hline Firm complex software use & -0.258 & $(2)$ & $(3)$ & 0.569 \\
& {$[0.222]$} & {$[0.211]$} & 0.594 & {$[0.256]^{* *}$} \\
\hline Dependent variable: & \multicolumn{4}{c}{ Panel C: Second-Stage - Firm task indexes } \\
\cline { 2 - 5 } & Abstract & Routine & Manual \\
& $(1)$ & $(2)$ & $(3)$ & \\
\hline Firm complex software use & -1.262 & 1.155 & 1.283 & \\
& {$[0.507]^{* *}$} & {$[0.470]^{* *}$} & $0.499]^{* *}$ & \\
Observations & 3,372 & 3,372 & 3,372 & \\
\hline
\end{tabular}

Notes: Robust standard errors in brackets clustered by region-sector. ** indicates significance at a 5 per cent confidence level. The table reports the 2SLS estimates of the second-stage given by Equation (4). All regressions control for firm and year fixed effects and include time-varying firm characteristics (size categories, age (in logs), exporter, foreign-owned, and credit constrained indicators, age (in logs), number of years of experience (in logs) and indicators for the degree of education of the main manager), time-varying region characteristics (average per capita household income (in logs), share of urban households, and average number of years of education of households (in logs)), number of computers used by firms in the region-sector, as well as region-specific time trends.

Table X. Firm Complex Software Use, Employment Composition and Task Indexes Excluding "Outlier" Sectors Utilities and Financial Intermediation and Region Antartica

\begin{tabular}{|c|c|c|c|c|}
\hline \multirow[t]{3}{*}{ Dependent variable: } & \multicolumn{4}{|c|}{ Panel B: Second-stage - Firm employment shares } \\
\hline & Managers & $\begin{array}{c}\text { Professionals \& } \\
\text { technical } \\
\text { workers }\end{array}$ & $\begin{array}{c}\text { Administ. } \\
\text { workers }\end{array}$ & $\begin{array}{c}\text { Unskilled } \\
\text { production \& } \\
\text { services } \\
\text { workers }\end{array}$ \\
\hline & (1) & (2) & (3) & (4) \\
\hline \multirow[t]{2}{*}{ Firm complex software use } & -0.250 & 0.232 & -0.560 & 0.578 \\
\hline & [0.219] & [0.200] & {$[0.254]^{\star *}$} & {$[0.258]^{\star *}$} \\
\hline \multirow[t]{2}{*}{ Dependent variable: } & \multicolumn{4}{|c|}{ Panel C: Second-Stage - Firm task indexes } \\
\hline & $\begin{array}{l}\text { Abstract } \\
\text { (1) }\end{array}$ & $\begin{array}{c}\text { Routine } \\
\text { (2) }\end{array}$ & $\begin{array}{c}\text { Manual } \\
\text { (3) }\end{array}$ & \\
\hline \multirow[t]{2}{*}{ Firm complex software use } & -1.247 & 1.118 & 1.259 & \\
\hline & {$[0.498]^{\star *}$} & {$[0.452]^{* *}$} & {$[0.487]^{* * *}$} & \\
\hline Observations & 3,322 & 3,322 & 3,322 & \\
\hline
\end{tabular}

Notes: Robust standard errors in brackets clustered by region-sector. ${ }^{* * *}$ and ${ }^{* *}$ indicate significance at 1 and 5 per cent confidence levels, respectively. The table reports the 2SLS estimates of the second-stage given by Equation (4). All regressions control for firm and year fixed effects and include time-varying firm characteristics (size categories, age (in logs), exporter, foreign-owned, and credit constrained indicators, age (in $\operatorname{logs}$ ), number of years of experience (in logs) and indicators for the degree of education of the main manager), time-varying region characteristics (average per capita household income (in logs), share of urban households, and average number of years of education of households (in logs)), number of computers used by firms in the region-sector, as well as region-specific time trends.

\subsection{Complex Software Adoption, Training and Outsourcing}

Can the reallocation of employment away from professionals and technical workers toward unskilled production and services workers due to the adoption of complex software lead firms to change their investments in worker training? Columns (1) to (3) of Table XI show that firms that 
adopt complex software do not significantly change their behavior regarding training provided to workers. However, following adoption, firms do increase the likelihood of providing ICT-specific training to the manager by approximately 20 percentage points. We ask whether firms adopting complex software engage in a reorganization process. One example is the extent of outsourcing activities as the adoption of complex software could require hiring services of workers for IT implementation and support. ${ }^{\text {xii }}$ Column (4) of Table XI reports the results of our main specification when the dependent variable is an indicator variable for whether the firm engages in outsourcing. Interestingly, there is a positive, though insignificant, relation across adoption and outsourcing.

Table XI. Firm Complex Software Adoption, Training and Outsourcing

\begin{tabular}{lcccc}
\hline \hline Dependent variable: & $\begin{array}{c}\text { Worker } \\
\text { training } \\
(1)\end{array}$ & $\begin{array}{c}\text { Manager } \\
\text { training }\end{array}$ & $\begin{array}{c}\text { Manager } \\
\text { training on ICT }\end{array}$ & Outsourcing \\
& $(2)$ & $(3)$ & $(4)$ \\
\hline Firm complex software use & 0.0479 & 0.164 & 0.195 & 0.140 \\
& {$[0.344]$} & {$[0.248]$} & {$[0.0988]^{* *}$} & {$[0.124]$} \\
Observations & 3,704 & 3,704 & 3,704 & 3,704 \\
\hline
\end{tabular}

Source: Authors' calculations based on ELE's 2007 and 2013 waves and 2014 Chile PIAAC survey.

Notes: Robust standard errors in brackets clustered by region-sector. $*^{* *}, * *$, and * indicate significance at 1,5 , and 10 per cent confidence levels, respectively. All regressions control for firm and year fixed effects and include time-varying firm characteristics (size categories, age (in logs), exporter, foreign-owned, and credit constrained indicators, age (in logs), number of years of experience (in logs) and indicators for the degree of education of the main manager), time-varying region characteristics (average per capita household income (in logs), share of urban households, and average number of years of education of households (in logs)), number of computers used by firms in the region-sector, as well as regionspecific time trends. The dependent variables are defined in Table A1 (Appendix). 


\subsection{Complete Results for Main Regressions}

Table XII. Complete Results for Main Regressions

\begin{tabular}{|c|c|c|c|c|c|c|c|c|c|c|c|}
\hline \multirow[b]{2}{*}{ Dependent variable: } & \multicolumn{4}{|c|}{ Panel A. Firm employment shares } & \multicolumn{3}{|c|}{ Panel B. Firm task indexes } & \multicolumn{4}{|c|}{ Panel C. Firm log of employment levels } \\
\hline & Managers & $\begin{array}{c}\text { Prof. \& } \\
\text { technical } \\
\text { workers }\end{array}$ & $\begin{array}{c}\text { Administ. } \\
\text { workers }\end{array}$ & $\begin{array}{l}\text { Unskilled } \\
\text { prod. \& } \\
\text { serv. } \\
\text { workers }\end{array}$ & Abstract & Routine & Manual & Managers & $\begin{array}{c}\text { Prof. \& } \\
\text { technical } \\
\text { workers }\end{array}$ & $\begin{array}{c}\text { Administ. } \\
\text { workers }\end{array}$ & $\begin{array}{c}\text { Unskilled } \\
\text { prod. \& } \\
\text { serv. } \\
\text { workers }\end{array}$ \\
\hline Firm complex software use & $\begin{array}{l}-0.270 \\
{[0.228]}\end{array}$ & $\begin{array}{c}-0.583 \\
{[0.258]^{* *}}\end{array}$ & $\begin{array}{c}0.282 \\
{[0.209]}\end{array}$ & $\begin{array}{c}0.571 \\
{[0.256]^{\star *}}\end{array}$ & $\begin{array}{c}-1.273 \\
{[0.506]^{\star *}}\end{array}$ & $\begin{array}{c}1.170 \\
{[0.473]^{\star *}}\end{array}$ & $\begin{array}{c}1.294 \\
{[0.499]^{\star \star *}}\end{array}$ & $\begin{array}{l}-0.764 \\
{[0.481]}\end{array}$ & $\begin{array}{l}-1.243 \\
{[0.869]}\end{array}$ & $\begin{array}{c}1.462 \\
{[0.814]^{*}}\end{array}$ & $\begin{array}{c}2.799 \\
{[1.136]^{\star \star}}\end{array}$ \\
\hline$=1$ if micro firm & $\begin{array}{c}0.0303 \\
{[0.0796]}\end{array}$ & $\begin{array}{l}-0.188 \\
{[0.127]}\end{array}$ & $\begin{array}{c}0.0659 \\
{[0.0635]}\end{array}$ & $\begin{array}{l}0.0921 \\
{[0.116]}\end{array}$ & $\begin{array}{l}-0.161 \\
{[0.211]}\end{array}$ & $\begin{array}{c}0.121 \\
{[0.181]}\end{array}$ & $\begin{array}{c}0.165 \\
{[0.207]}\end{array}$ & $\begin{array}{c}-0.602 \\
{[0.141]^{\star \star \star}}\end{array}$ & $\begin{array}{c}-1.193 \\
{[0.442]^{\star * *}}\end{array}$ & $\begin{array}{c}-0.496 \\
{[0.227]^{\star *}}\end{array}$ & $\begin{array}{l}-0.637 \\
{[0.440]}\end{array}$ \\
\hline$=1$ if small firm 1 & $\begin{array}{c}0.0524 \\
{[0.0457]}\end{array}$ & $\begin{array}{l}-0.118 \\
{[0.102]}\end{array}$ & $\begin{array}{c}0.0573 \\
{[0.0591]}\end{array}$ & $\begin{array}{c}0.00803 \\
{[0.107]}\end{array}$ & $\begin{array}{c}-0.00200 \\
{[0.188]}\end{array}$ & $\begin{array}{c}-0.00707 \\
{[0.154]}\end{array}$ & $\begin{array}{c}0.00864 \\
{[0.185]}\end{array}$ & $\begin{array}{c}-0.382 \\
{[0.121]^{\star \star \star}}\end{array}$ & $\begin{array}{c}-1.053 \\
{[0.354]^{\star * *}}\end{array}$ & $\begin{array}{c}-0.464 \\
{[0.224]^{\star *}}\end{array}$ & $\begin{array}{c}-0.753 \\
{[0.412]^{*}}\end{array}$ \\
\hline$=1$ if small firm 2 & $\begin{array}{c}0.0554 \\
{[0.0388]}\end{array}$ & $\begin{array}{l}-0.0441 \\
{[0.0805]}\end{array}$ & $\begin{array}{c}0.0263 \\
{[0.0431]}\end{array}$ & $\begin{array}{c}-0.0375 \\
{[0.0679]}\end{array}$ & $\begin{array}{l}0.0901 \\
{[0.120]}\end{array}$ & $\begin{array}{r}-0.0859 \\
{[0.102]}\end{array}$ & $\begin{array}{r}-0.0858 \\
{[0.119]}\end{array}$ & $\begin{array}{c}-0.334 \\
{[0.108]^{\star * *}}\end{array}$ & $\begin{array}{c}-0.706 \\
{[0.298]^{\star *}}\end{array}$ & $\begin{array}{c}-0.545 \\
{[0.158]^{\star \star *}}\end{array}$ & $\begin{array}{c}-0.727 \\
{[0.285]^{* *}}\end{array}$ \\
\hline$=1$ if medium-size firm & $\begin{array}{c}0.0430 \\
{[0.0218]^{* *}}\end{array}$ & $\begin{array}{c}0.0342 \\
{[0.0473]}\end{array}$ & $\begin{array}{l}-0.0216 \\
{[0.0288]}\end{array}$ & $\begin{array}{l}-0.0557 \\
{[0.0509]}\end{array}$ & $\begin{array}{c}0.134 \\
{[0.0909]}\end{array}$ & $\begin{array}{c}-0.128 \\
{[0.0754]^{*}}\end{array}$ & $\begin{array}{c}-0.135 \\
{[0.0894]}\end{array}$ & $\begin{array}{c}-0.175 \\
{[0.0763]^{\star *}}\end{array}$ & $\begin{array}{l}-0.252 \\
{[0.204]}\end{array}$ & $\begin{array}{c}-0.531 \\
{[0.128]^{\star * *}}\end{array}$ & $\begin{array}{c}-0.672 \\
{[0.197]^{\star * *}}\end{array}$ \\
\hline $\log c$ & $\begin{array}{l}-0.00257 \\
{[0.0283]}\end{array}$ & $\begin{array}{c}0.0718 \\
{[0.0492]}\end{array}$ & $\begin{array}{l}0.00637 \\
{[0.0286]}\end{array}$ & $\begin{array}{l}-0.0756 \\
{[0.0522]}\end{array}$ & $\begin{array}{c}0.120 \\
{[0.108]}\end{array}$ & $\begin{array}{l}-0.0790 \\
{[0.0966]}\end{array}$ & $\begin{array}{l}-0.114 \\
{[0.108]}\end{array}$ & $\begin{array}{c}0.112 \\
{[0.0733]}\end{array}$ & $\begin{array}{c}0.249 \\
{[0.105]^{\star \star}}\end{array}$ & $\begin{array}{l}0.0215 \\
{[0.150]}\end{array}$ & $\begin{array}{l}-0.267 \\
{[0.257]}\end{array}$ \\
\hline$=1$ if exporting firm & $\begin{array}{c}-0.0781 \\
{[0.0398]^{\star *}}\end{array}$ & $\begin{array}{c}-0.0252 \\
{[0.0602]}\end{array}$ & $\begin{array}{c}0.0269 \\
{[0.0380]}\end{array}$ & $\begin{array}{c}0.0765 \\
{[0.0603]}\end{array}$ & $\begin{array}{l}-0.196 \\
{[0.131]}\end{array}$ & $\begin{array}{c}0.196 \\
{[0.121]}\end{array}$ & $\begin{array}{c}0.199 \\
{[0.131]}\end{array}$ & $\begin{array}{l}-0.152 \\
{[0.116]}\end{array}$ & $\begin{array}{c}0.130 \\
{[0.205]}\end{array}$ & $\begin{array}{c}0.239 \\
{[0.200]}\end{array}$ & $\begin{array}{c}0.418 \\
{[0.272]}\end{array}$ \\
\hline$=1$ if foreign firm & $\begin{array}{l}-0.00440 \\
{[0.0387]}\end{array}$ & $\begin{array}{c}0.142 \\
{[0.0745]^{*}}\end{array}$ & $\begin{array}{l}-0.0483 \\
{[0.0433]}\end{array}$ & $\begin{array}{c}-0.0889 \\
{[0.0872]}\end{array}$ & $\begin{array}{c}0.166 \\
{[0.159]}\end{array}$ & $\begin{array}{l}-0.133 \\
{[0.128]}\end{array}$ & $\begin{array}{l}-0.168 \\
{[0.154]}\end{array}$ & $\begin{array}{l}0.0363 \\
{[0.173]}\end{array}$ & $\begin{array}{c}0.679 \\
{[0.383]^{*}}\end{array}$ & $\begin{array}{l}-0.215 \\
{[0.205]}\end{array}$ & $\begin{array}{l}-0.338 \\
{[0.418]}\end{array}$ \\
\hline$=1$ if firm is credit constraint & $\begin{array}{c}0.0895 \\
{[0.0820]}\end{array}$ & $\begin{array}{l}-0.146 \\
{[0.102]}\end{array}$ & $\begin{array}{l}0.00728 \\
{[0.0322]}\end{array}$ & $\begin{array}{c}0.0496 \\
{[0.0436]}\end{array}$ & $\begin{array}{l}-0.0196 \\
{[0.0915]}\end{array}$ & $\begin{array}{c}-0.0388 \\
{[0.108]}\end{array}$ & $\begin{array}{c}0.0140 \\
{[0.0946]}\end{array}$ & $\begin{array}{c}0.00158 \\
{[0.112]}\end{array}$ & $\begin{array}{c}-0.506 \\
{[0.291]^{*}}\end{array}$ & $\begin{array}{l}0.0204 \\
{[0.112]}\end{array}$ & $\begin{array}{c}0.169 \\
{[0.169]}\end{array}$ \\
\hline Log of managers's age & $\begin{array}{l}-0.0236 \\
{[0.0583]}\end{array}$ & $\begin{array}{l}0.0795 \\
{[0.120]}\end{array}$ & $\begin{array}{c}0.0525 \\
{[0.0935]}\end{array}$ & $\begin{array}{l}-0.108 \\
{[0.131]}\end{array}$ & $\begin{array}{c}0.136 \\
{[0.254]}\end{array}$ & $\begin{array}{l}-0.0583 \\
{[0.220]}\end{array}$ & $\begin{array}{l}-0.120 \\
{[0.252]}\end{array}$ & $\begin{array}{l}-0.117 \\
{[0.212]}\end{array}$ & $\begin{array}{l}-0.144 \\
{[0.331]}\end{array}$ & $\begin{array}{c}-0.0862 \\
{[0.280]}\end{array}$ & $\begin{array}{c}-0.541 \\
{[0.566]}\end{array}$ \\
\hline $\begin{array}{l}\text { Log of managers's } \\
\quad \text { years of experience }\end{array}$ & $\begin{array}{c}0.0245 \\
{[0.0181]}\end{array}$ & $\begin{array}{l}-0.00448 \\
{[0.0317]}\end{array}$ & $\begin{array}{l}-0.0251 \\
{[0.0203]}\end{array}$ & $\begin{array}{l}0.00513 \\
{[0.0316]}\end{array}$ & $\begin{array}{c}0.0214 \\
{[0.0621]}\end{array}$ & $\begin{array}{l}-0.0405 \\
{[0.0536]}\end{array}$ & $\begin{array}{l}-0.0268 \\
{[0.0613]}\end{array}$ & $\begin{array}{c}0.0663 \\
{[0.0504]}\end{array}$ & $\begin{array}{c}-0.00143 \\
{[0.108]}\end{array}$ & $\begin{array}{c}-0.100 \\
{[0.0660]}\end{array}$ & $\begin{array}{l}-0.0266 \\
{[0.132]}\end{array}$ \\
\hline $\begin{array}{c}=1 \text { if manager has medium } \\
\text { level of education }\end{array}$ & $\begin{array}{l}-0.0326 \\
{[0.0369]}\end{array}$ & $\begin{array}{l}-0.0267 \\
{[0.0678]}\end{array}$ & $\begin{array}{c}0.0644 \\
{[0.0339]^{*}}\end{array}$ & $\begin{array}{l}-0.00512 \\
{[0.0764]}\end{array}$ & $\begin{array}{c}-0.0460 \\
{[0.141]}\end{array}$ & $\begin{array}{l}0.0791 \\
{[0.116]}\end{array}$ & $\begin{array}{l}0.0581 \\
{[0.138]}\end{array}$ & $\begin{array}{l}-0.0432 \\
{[0.0863]}\end{array}$ & $\begin{array}{l}-0.119 \\
{[0.151]}\end{array}$ & $\begin{array}{c}0.156 \\
{[0.139]}\end{array}$ & $\begin{array}{c}0.191 \\
{[0.280]}\end{array}$ \\
\hline $\begin{array}{r}=1 \text { if manager has high } \\
\text { level of education }\end{array}$ & $\begin{array}{l}-0.0720 \\
{[0.0459]}\end{array}$ & $\begin{array}{l}-0.0214 \\
{[0.0796]}\end{array}$ & $\begin{array}{c}0.0684 \\
{[0.0439]}\end{array}$ & $\begin{array}{c}0.0250 \\
{[0.0963]}\end{array}$ & $\begin{array}{l}-0.126 \\
{[0.178]}\end{array}$ & $\begin{array}{c}0.161 \\
{[0.145]}\end{array}$ & $\begin{array}{c}0.139 \\
{[0.173]}\end{array}$ & $\begin{array}{r}-0.0742 \\
{[0.112]}\end{array}$ & $\begin{array}{r}-0.0490 \\
{[0.180]}\end{array}$ & $\begin{array}{c}0.146 \\
{[0.156]}\end{array}$ & $\begin{array}{c}0.300 \\
{[0.346]}\end{array}$ \\
\hline $\begin{array}{l}\text { Log of regional avg. per } \\
\text { capita hhld income }\end{array}$ & $\begin{array}{l}0.0228 \\
{[0.592]}\end{array}$ & $\begin{array}{l}-1.553 \\
{[1.514]}\end{array}$ & $\begin{array}{c}0.258 \\
{[0.840]}\end{array}$ & $\begin{array}{c}0.394 \\
{[2.593]}\end{array}$ & $\begin{array}{l}-2.376 \\
{[2.379]}\end{array}$ & $\begin{array}{c}1.683 \\
{[1.839]}\end{array}$ & $\begin{array}{c}1.787 \\
{[2.196]}\end{array}$ & $\begin{array}{l}-2.816 \\
{[1.782]}\end{array}$ & $\begin{array}{l}-6.731 \\
{[4.583]}\end{array}$ & $\begin{array}{c}0.796 \\
{[2.863]}\end{array}$ & $\begin{array}{l}-0.598 \\
{[3.840]}\end{array}$ \\
\hline $\begin{array}{l}\text { Regional share of urban } \\
\text { households }\end{array}$ & $\begin{array}{l}-10.07 \\
{[7.804]}\end{array}$ & $\begin{array}{c}26.56 \\
{[17.83]}\end{array}$ & $\begin{array}{c}1.076 \\
{[9.472]}\end{array}$ & $\begin{array}{l}-4.929 \\
{[31.92]}\end{array}$ & $\begin{array}{c}18.67 \\
{[29.45]}\end{array}$ & $\begin{array}{l}-7.149 \\
{[23.87]}\end{array}$ & $\begin{array}{l}-24.68 \\
{[30.48]}\end{array}$ & $\begin{array}{c}3.624 \\
{[17.31]}\end{array}$ & $\begin{array}{c}70.80 \\
{[57.59]}\end{array}$ & $\begin{array}{l}-0.292 \\
{[31.36]}\end{array}$ & $\begin{array}{c}44.15 \\
{[45.30]}\end{array}$ \\
\hline $\begin{array}{l}\text { Log of regional avg. years } \\
\text { of education }\end{array}$ & $\begin{array}{c}1.118 \\
{[3.010]}\end{array}$ & $\begin{array}{l}-4.916 \\
{[5.114]}\end{array}$ & $\begin{array}{l}-2.209 \\
{[3.314]}\end{array}$ & $\begin{array}{l}-1.189 \\
{[15.19]}\end{array}$ & $\begin{array}{l}-6.628 \\
{[8.815]}\end{array}$ & $\begin{array}{c}3.493 \\
{[7.856]}\end{array}$ & $\begin{array}{c}10.35 \\
{[11.88]}\end{array}$ & $\begin{array}{l}-2.904 \\
{[6.712]}\end{array}$ & $\begin{array}{l}-0.866 \\
{[23.04]}\end{array}$ & $\begin{array}{l}-0.405 \\
{[8.746]}\end{array}$ & $\begin{array}{l}-7.001 \\
{[13.05]}\end{array}$ \\
\hline Observations & 3,704 & 3,704 & 3,704 & 3,704 & 3,704 & 3,704 & 3,704 & 3,704 & 3,704 & 3,704 & 3,704 \\
\hline
\end{tabular}

Notes: Robust standard errors in brackets clustered by region-sector. $* * *, * *$, and * indicate significance at 1,5 , and 10 per cent confidence levels, respectively. All regressions control for firm and year fixed effects, number of computers used by firms in the region-sector, as well as regionspecific time trends. The dependent variables are defined in Table A1 (Appendix). 
${ }^{\mathrm{i}}$ Variables measuring the frequency of a particular abstract activity are expressed on a scale ranging from 1 (indicating very low frequency) to 5 (indicating very high frequency). We follow Autor et al. (2003) in including interactive tasks (interaction with other people at work) in the definition of abstract tasks.

ii Variables measuring the rigidity of a particular activity are expressed on a scale ranging from 1 (indicating little rigidity) to 5 (indicating strong rigidity). Our definition of routine tasks follows the definition used by other papers using the PIAAC surveys (Marcolin et al., 2016; Pouliakas and Russo, 2015).

iii Our definition of manual tasks follows Autor and Handel (2013) in including a proxy for manual dexterity.

iv A matrix with the matches between detailed occupations and occupation categories is available upon request.

${ }^{v}$ Total hours of work in the previous week are obtained as the sum of hours of work in the previous week by all existing detailed occupations (regardless of which occupation category in ELE they are mapped to).

vi This variable is interacted with the sector ICT intensity in 2003 obtained from the Chilean Input-Output matrix.

${ }^{v i i}$ We identify in the PIAAC survey three aggregate sectors (primary, manufacturing and services) and we measure the abstract, routine, and manual task content for the four occupations separately in each of these sectors.

viii The first-stage coefficients corresponding to the various robustness checks are all positive and significant at standard confidence levels.

ix These results are available from the authors upon request.

${ }^{\mathrm{x}}$ The impacts are significant in most robustness checks with the exception being the specification estimated ignoring the panel structure of the data where there is no statistically significant impact for the abstract index.

${ }^{x i}$ ELE does not identify for each firm in the manufacturing or wholesale and retail sectors the sub-industry in which it operates, hence we can only exclude those very broad sectors in this exercise.

xii Of course, such IT implementation and support services can also be provided by in-house services workers.

\section{References}

Acemoglu, D., \& Autor, D. (2011). Skills, Tasks and Technologies: Implications for Employment and Earnings. In Orley Ashenfelter and David Card (eds.) Handbook of Labor Economics, Vol. 4, Part B, 1043-1171. Amsterdam: Elsevier.

Autor, D., Levy, F., \& Murnane, R. (2003). The Skill Content of Recent Technological Change: An Empirical Exploration. Quarterly Journal of Economics, 118(4), 1279-1333.

Autor, D., \& Handel, M. J. (2013). Putting Tasks to the Test: Human Capital, Job Tasks, and Wages. Journal of Labor Economics, 31(2), 59-96.

Marcolin, L., Miroudot, S., \& Squicciarini, M. (2016). The Routine Content of Occupations: New Cross-Country Measures Based On PIAAC. OECD Trade Policy Papers 188, Paris, France.

Messina, J., Oviedo, A.M., \& Pica, G. (2016). Job Polarization in Latin America. Mimeo, The World Bank, Washington, DC.

Pouliakas, K., \& Russo, G. (2015). Heterogeneity of Skills Needs and Job Complexity: Evidence from the OECD PIAAC Survey. IZA Discussion Paper 9392, IZA Institute of Labor Economics. 